\title{
Bioenergy plants' potential for contributing to heat generation in Germany
}

\author{
M. Steubing ${ }^{1 *}$, M. Dotzauer ${ }^{2}$, T. Zakaluk ${ }^{2}$, B. Wern ${ }^{3}$, F. Noll ${ }^{3}$ and D. Thraen ${ }^{1,2}$
}

\begin{abstract}
Background: The Paris Climate Agreement requires a rapid and efficient shift to renewable energies and a decarbonization of the energy system. Combined heat and power provision from biomass is one way to efficiently provide renewable heat. Despite this, many bioenergy plants in Germany are mainly used to generate electricity and the provision of externally usable heat still has untapped potential. In this study, we investigated gross quantities as well as the economically viable potential of Germany's current bioenergy plant stock in supplying renewable heat.
\end{abstract}

Methods: We used a top-down GIS modeling approach to spatially and explicitly assess the heat demand of three different categories of heat sinks at sub-municipal level. These included residential, commercial, and industrial areas, as well as large individual heat consumers. We then calculated the plant-specific heat sales potential for two different district heating network options. In addition, we developed a method for assessing the economic efficiency of the previously identified technical heat sales volume for a set of 20 different clusters of bioenergy plants.

Results: The results show that about 50\% of the bioenergy plants have potential heat consumers in their immediate proximity. The overall technical heat sales potential for all three categories totals around $150 \mathrm{TWh}_{\mathrm{th}} / \mathrm{a}$. However, this potential is not evenly distributed throughout Germany. Certain regions appear to be more favorable for investing in district heating networks powered by heat from biomass. The economically viable heat sales potential related to electrical energy generation ranges from -0.128 to $0.160 € / \mathrm{kWh}$ th.

Conclusion: We concluded that, under certain conditions such as location or supply and demand structure, German bioenergy plants have the potential to provide a significant share to renewable energies in the heating sector. In addition, the heat sales potential is highly relevant for plant operators as the importance of heat as a business segment is set to increase. Furthermore, bioenergy plants could contribute $2.1 \%\left(16.3 \mathrm{TWh}_{\mathrm{th}} / \mathrm{a}\right)$ to the total demand for space heating in Germany (765 TWh $\mathrm{th}_{\mathrm{th}} / \mathrm{a}$ ) when considering certain technical and economic constraints.

Keywords: Bioenergy CHP, Renewable heat, District heating networks, GIS modeling

\section{Background}

Heat accounts for half of the final energy consumption in Germany, but currently only $13.9 \%$ of heat is supplied by renewable energy sources (RES) [1]. Thus, the share of renewable energy sources in heat supply needs

\footnotetext{
*Correspondence: michael.steubing@ufz.de

${ }^{1}$ Helmholtz Centre for Environmental Research, Permoserstrasse 15, 04318 Leipzig, Germany

Full list of author information is available at the end of the article
}

to increase if the greenhouse gas reduction targets of the Paris Climate Agreement are to be met. In order to achieve this goal, the European Union (EU) intends to analyze different ways to promote a transition towards using RES in supplying heat as part of its strategy on heating and cooling (COM 2016). One option is to decarbonize existing district heating networks (DHNs) and to supply more heat consumers through new, yetto-be-built DHNs. At the moment, district heating

C C The Author(s). 2020 Open Access This article is licensed under a Creative Commons Attribution 4.0 International License, which permits use, sharing, adaptation, distribution and reproduction in any medium or format, as long as you give appropriate credit to the original author(s) and the source, provide a link to the Creative Commons licence, and indicate if changes were made. The images or other third party material in this article are included in the article's Creative Commons licence, unless indicated otherwise in a credit line to the material. If material is not included in the article's Creative Commons licence and your intended use is not permitted by statutory regulation or exceeds the permitted use, you will need to obtain permission directly from the copyright holder. To view a copy of this licence, visit http://creativecommons.org/licenses/by/4.0/ The Creative Commons Public Domain Dedication waiver (http://creativecommons.org/publicdomain/zero/1.0/) applies to the data made available in this article, unless otherwise stated in a credit line to the data. 
provides 9\% of the EU's heat [2]. In 2012, fossil fuels were the primary energy sources for heating and cooling in these networks (75\%). The most important renewable fuel for DHNs, with a share of $12 \%$ in 2015 , is heat generated from biomass [3].

In 2012, Germany's share in final energy consumption for heating and cooling supplied by district heating systems was 8-9\% [2]. The German district heating system ${ }^{1}$ has a connected load of $51 \mathrm{GW}$ and a transformation output of around 470 PJ. The overall fuel input amounts to $522.3 \mathrm{PJ}$ and consists of coal (29\%), lignite (11\%), mineral oil (1\%), natural gas $(42 \%)$, waste $(11 \%)$, and biomass $(6 \%)$ [4]. However, in order to achieve the greenhouse gas reduction targets set by the German government, DHNs supplied by RES will need to provide $23 \%$ of the final energy consumption for building heat by 2050 [5]. One reason for this is that regions without a natural gas network and with predominantly decentralized oil heating systems also need to have renewable alternatives for their so far fossil-based heat supply [6]. Furthermore, with the foreseeable shutdown of coalfired power plants in Germany by 2038 [7], the 50 $\mathrm{TWh}_{\mathrm{th}} / \mathrm{a}$ of heat [8] currently produced by this sector needs to be replaced by low-carbon fuels. Fritz and Pehnt [8] recently stated that biomass must also partly contribute to this as well.

The largest share of heat from RES in Germany is generated by biomass $(87.3 \%)$, mainly in small combustion plants [9]. Additionally, Germany has an installed capacity of $5.6 \mathrm{GW}_{\mathrm{el}}[10]$ in biogas plants and $1.6 \mathrm{GW}_{\mathrm{el}}[10]$ in plants using solid biomass fuels, which are currently not utilizing all of the available heat [11].

DHNs are a suitable way of increasing the use of RES in the heating sector, as Lund et al. point out [12]. This particularly applies to biomass. Bio-fueled combined heat and power units (CHPU) can achieve an overall efficiency of up to $90 \%$ [13]. The co-generated heat can be used to supply DHNs. In order to fully exploit this potential, however, suitable heat consumers (heat sinks) must be located near the plants; otherwise, the generated heat cannot be supplied properly due to transportrelated energy losses. The plant-specific and, consequently, the total heat supply potential of the bioenergy plants (BEPs) in Germany thus crucially depends on plant location.

In current energy scenarios for Germany, there is little information available specifically on local district heating networks and the fuels being used there. Koch et al. [14] stated an overall contribution to the generation of heat of $16 \mathrm{TWh}$ with natural gas being the dominant fuel. Biomass only plays a minor role in the supply of these

\footnotetext{
${ }^{1}$ Without rural local district heating networks fueled by heat generated from biomass.
}

networks but with increasing proportions until 2050 [14].

Against this backdrop, the question arises as to the extent to which the current BEP installations in Germany can contribute to the provision of heat to external users by means of district heating networks. In this study, we investigate the gross amount of heat demand and supply of the German BEP stock as well as the economically viable potential. For this purpose, we seek to answer the following research questions:

- How many BEPs have nearby heat sinks suitable for a DHN?

- What is the extent of the technical heat sales potential (tHSP) (in $\mathrm{TWh}_{\mathrm{th}} / \mathrm{a}$ ) of these BEPs?

- How can the economic viability of tHSP be assessed?

- How high is the economically viable heat sales potential (eHSP)?

To answer these questions, we modeled the heat demand for three different categories of heat sinks at a sub-municipal spatial resolution: the residential sector (1), the industrial sector as well as the sector trade, commerce and services (TCS) (2), and large individual heat consumers (LIHC) such as hospitals and schools (3). We then evaluated which BEPs are capable of delivering heat at all, as well as the plant-specific and overall heat sales potential per category.

Additionally, we developed a method to evaluate the economic viability of the previously assessed technical heat sales for a set of 20 different clusters of BEPs.

In the context of modeling future energy systems, Weinand et al. emphasize the need for data at a high spatial resolution [15]. While the general potential for DHNs in Germany has been analyzed before [16], an investigation into the specific potential of bio-fueled CHPUs has only been carried out in some states, such as Saarland [17]. A Germany-wide assessment has yet to be made.

\section{Methods \\ Modeling scheme}

In order to determine the technical heat sales potential (tHSP) for each plant individually, it is necessary to identify suitable heat sinks close to the respective plant. Consequently, the tHSP is defined as the heat demand of suitable heat sinks within a defined maximum distance to the respective BEP. While spatial information on BEPs is available through the bioenergy plant database of the German Biomass Research Centre (DBFZ) [18], the spatially explicit heat demand related to these plants is missing and needs to be identified. The modeling consisted of two separate steps. First, we modeled the heat 
demand at a spatial resolution below the municipal level. For the residential sector, this means the level of individual residential blocks and for the industrial sector the level of industrial and commercial areas as recorded in the ATKIS Basis Digital Landscape Model (DLM) [19]. The ATKIS Basis DLM offers a description of these topographic elements in vector data format for all of Germany on a scale of 1:25,000 [19]. For the LIHC, this means their exact geographical location. In a second step, we calculated the tHSP for each plant individually and concluded the overall tHSP.

Based on the tHSP, we developed an estimation approach to assess the economically viable heat sales potential (eHSP, see Fig. 5). The basic method for calculating tHSP as well as the input data used is illustrated in Fig. 1.

Most of the data used in the model is publicly available. The content of the respective datasets, their origin and the latest update are listed in Table 1. Only the municipal level heat demand (later referred to as "IZES heat demand") and the DBFZ BEP database contain internal data of the respective institutions and are therefore not publicly available.

\section{Modeling the heat demand at a high spatial resolution}

Heat is required and consumed in three different sectors: residential, TCS, and industrial. As the German
Environment Agency states, heat in the residential and TCS sectors is primarily required for space heating, while the industrial sector requires the largest share for process heat [1]. Consequently, the methods for determining the total heat demand per sector and for its spatial modeling vary.

For the residential, TCS and industrial sectors, we followed a top-down modeling approach as described by Fleiter et al. and applied by Baur et al. [3, 17]. The basic principle of this approach is to disaggregate the heat demand from the existing aggregated level into smaller spatial units. In our case, we used data on the heat demand per sector for each municipality, calculated by Baur et al. [20], and allocated it to the residential areas and the commercial and/or industrial areas of each community.

We simultaneously applied a bottom-up approach for LIHCs, such as hospitals, commercial greenhouses, schools, and public outdoor swimming pools, which are particularly suitable for DHNs fueled by heat generated from biomass [26]. This means that we calculated their yearly heat demand on the basis of an object-specific key such as $\mathrm{kWh}_{\mathrm{th}} \mathrm{a} /$ bed (hospitals), $\mathrm{kWh}_{\mathrm{th}} \mathrm{a} /$ student (schools), $\mathrm{kWh}_{\mathrm{th}} \mathrm{a} / \mathrm{m}^{2}$ (commercial greenhouses), and $\mathrm{kWh}_{\mathrm{th}} \mathrm{a} / \mathrm{m}^{2}$ water surface (public outdoor swimming pools).

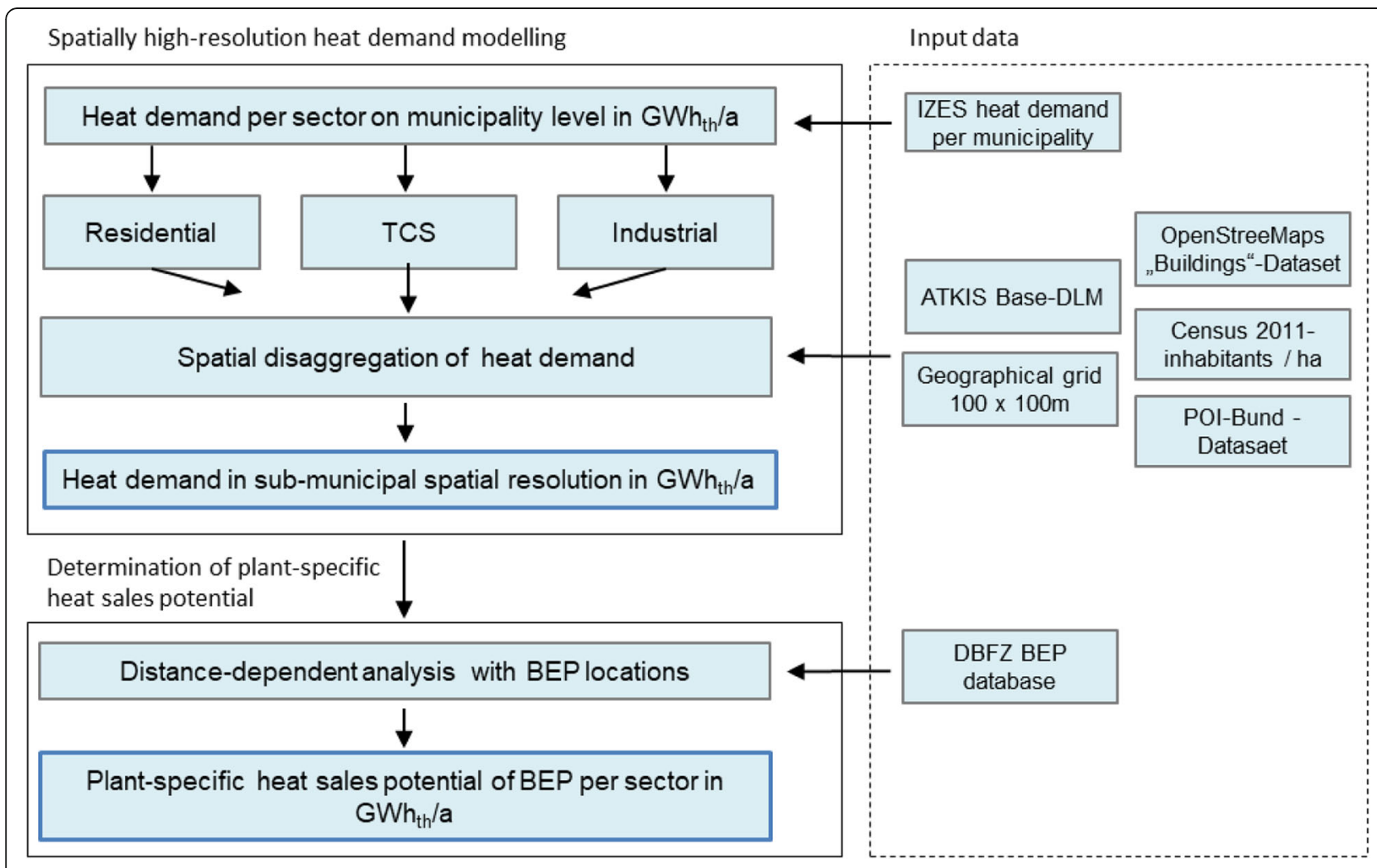

Fig. 1 Modeling scheme to identify plant-specific heat supply potential. The models of the input data are further described in Table 1 
Table 1 Data used for modeling heat demand

\begin{tabular}{|c|c|c|c|}
\hline Name & Content & Source & Update \\
\hline IZES heat demand & $\begin{array}{l}\text { Heat demand in } \mathrm{GWh}_{\mathrm{th}} / \mathrm{a} \text { on a municipal level for the residential, TCS, and } \\
\text { industrial sectors }\end{array}$ & $\begin{array}{l}\text { IZES gGmbH, Wuppertal Institut, } \\
\text { Fraunhofer UMSICHT [20] }\end{array}$ & 2011 \\
\hline DBFZ BEP database & $\begin{array}{l}\text { Locations and technical information on bioenergy plants in Germany, } \\
\text { containing approx. } 14,000 \text { individual plants }\end{array}$ & DBFZ & 2016 \\
\hline ATKIS basis DLM & $\begin{array}{l}\text { Digital landscape model (scale 1:25,000) with spatial and content-related } \\
\text { information on land use in vector data format }\end{array}$ & (oGeoBasis-DE/BKG [19] & 2012 \\
\hline Administrative areas & $\begin{array}{l}\text { Administrative areas of Germany (NUTS 0-3, LAU 1-2) including population } \\
\text { figures }\end{array}$ & oGeoBasis-DE/BKG [21] & 2016 \\
\hline Geographical grid & Geographical grid of Germany with a raster cell size of $100 \mathrm{~m} \times 100 \mathrm{~m}$ & (oGeoBasis-DE/BKG [22] & 2018 \\
\hline POI-Bund & Locations and additional information on schools and hospitals & (oGeoBasis-DE/BKG [23] & 2018 \\
\hline OSM buildings & OpenStreetMap buildings dataset & $\begin{array}{l}\text { Geofabrik GmbH, OpenStreetMap, and } \\
\text { contributors [24] }\end{array}$ & 2018 \\
\hline Census 2011 & Small-scale (raster cells, $100 \mathrm{~m} \times 100 \mathrm{~m}$ ) population statistics for Germany & Destatis (Federal Statistical Office) [25] & 2015 \\
\hline
\end{tabular}

\section{Residential sector}

The heat demand of residential units on a municipal level was assessed using building stock grouped by building type (single family dwelling, townhouse, etc.), year of construction, and municipality. This data was extracted from the 2011 census database [27]. We multiplied the number of buildings, divided into building class and municipality, by the corresponding heat demand in $\mathrm{kWh}_{\mathrm{th}} / \mathrm{a}$ and respective residential unit, derived from the German building typology of IWU 2003 [28]. Additionally, we took an average annual domestic hot water demand of $500 \mathrm{kWh}_{\text {th }}$ per capita into account, based on the municipal population on December 31, 2011 [27]. The overall methodology of assessing the heat demand is discussed in more detail in Baur et al. [20].

Within the ATKIS Basis DLM, the utilization of a given area is defined by unique codes related to object type. Subsequently, we selected all objects that are assigned to the residential sector including the object types 2102 (dwelling), 2111 (residential area), and 2113 (area of mixed use). These objects were then labeled as residential area objects (RAO) and are hereinafter referred to as such. All other objects (e.g., parks, bodies of water, train tracks, and stations) were no longer considered in the model and were therefore removed from our analysis. We then calculated the residential area factor $(R A F)$, which represents the share of each individual RAO in the total residential area of the municipality, with

$$
R A F=\frac{A_{\mathrm{RAO}}}{A_{\text {total residential area }}}
$$

where RAF is the residential area factor, RAO is the residential area object, and $A$ is the area $\left(\mathrm{m}^{2}\right)$.

Since the heat demand in the residential sector also depends on the number of inhabitants per area, it was necessary to determine the number of inhabitants for each RAO individually. To do so, we used population data from the 2011 census which is available in a nationwide grid with raster cell sizes of $100 \mathrm{~m} \times 100 \mathrm{~m}^{2}$ [25] The geodata for the grid is provided by the German Federal Agency for Cartography and Geodesy (BKG) [22]. We intersected the RAOs with the population data and calculated the population figures per $\mathrm{RAO}^{3}$. Subsequently, we determined the population factor $(P F)$, which is the ratio of any given RAO to the municipality's total population with

$$
P F=\frac{\text { Inhabitants per RAO }}{\text { Inhabitants of municipality }}
$$

where PF is the population factor and RAO is the residential area object.

In the next step, we calculated the RAO-specific heat demand using the heat demand per municipality provided by IZES in combination with the previously introduced factors RAF and PF. For RAOs containing information on the number of inhabitants, the specific heat demand $(Q)$ is

$$
Q_{\mathrm{RAO}}=Q_{\text {municipality }} \times P F
$$

where $Q$ is the heat demand $\left(G W h_{t h} / a\right)$, PFis the population factor, and RAO is the residential area object.

For RAOs with missing information on the number of inhabitants it is

\footnotetext{
${ }^{2}$ To protect privacy, grid cells with one person are identified as grid cells without persons and grid cells with only two persons are identified as grid cells with three persons [29].

${ }^{3} 75 \%$ of the residential area objects are covered by grid cells with more than one inhabitant.
} 


$$
Q_{R A O}=Q_{\text {municipality }} * R A F
$$

where $\mathrm{Q}$ is the heat demand $\left(\mathrm{GWh}_{\mathrm{th}} / \mathrm{a}\right), \mathrm{PF}$ is the residential area factor, and RAO is the residential area object.

Finally, the heat density $\left(\mathrm{kWh}_{\mathrm{th}} / \mathrm{m}^{2} \mathrm{a}\right)$ was determined for each RAO by dividing the RAO-specific heat demand $\left(\mathrm{GWh}_{\text {th }} / \mathrm{a}\right)$ by its area.

$$
H D_{R A O}=\left(\frac{Q_{R A O}}{A_{R A O}}\right)
$$

where HD is the heat density $\left(\mathrm{kWh}_{\mathrm{th}} / \mathrm{m}^{2} \mathrm{a}\right), \mathrm{Q}$ is the heat demand $\left(\mathrm{kWh}_{\mathrm{th}} / \mathrm{a}\right), \mathrm{A}$ is the area $\left(\mathrm{m}^{2}\right)$, and $\mathrm{RAO}$ is the residential area object.

The result is a dataset for the whole of Germany with very detailed spatial information on the heat demand and heat density of residential areas.

\section{TCS and industrial sector}

The heat demand of the industrial sector on a district level (NUTS 3) was estimated by multiplying the number of employees in the manufacturing sector ${ }^{4}$ by the corresponding average heat demand per employee and industry derived from the national statistic on industrial energy demand [31, 32]. Due to the lack of corresponding data for the TCS sector, we determined the heat demand of the TCS sector by using the gross added values of the related economic sectors ${ }^{5}$ [33]. They were multiplied by the average heat demand of the corresponding sectors derived from the reference scenario, which is described by Kirchner et al. [34]. In order to also determine the heat demand of both the TCS and industrial sector on a municipal level (LAU 2), we multiplied the calculated heat demands by the ratio of the number of employees at a municipal and district level [35].

As with the residential sector, the DLM was the basis for modeling the heat demand for the TCS and industrial sectors. Here, we used the object types "Industrial and commercial area" (2112) and "Area with special functional characteristics" (2114). We recognized that the DLM alone is only partially suitable for spatially modeling the heat demand of industrial and TCS areas. There are numerous objects (areas) assigned in the classification 2112 that have not been developed, as well as objects which do not have actual heat demand, like landfills or substations. To exclude such areas from the assessment, we added the OpenStreetMap (OSM) buildings dataset to the model [24]. During the modeling process, we only considered the DLM objects which

\footnotetext{
${ }^{4}$ The manufacturing sector includes the economic sectors classified by WZ08-10 to WZ08-33 according to the German Classification of Economic Activities, 2008 edition [30].
}

${ }^{5}$ Meant here are all economic sectors except the manufacturing sector. intersect with the OSM buildings dataset. We then created new area objects by calculating minimum boundary polygons around the buildings inside the objects classified as 2112 and 2114 and labeled them as "TCS area objects." Analogous to the residential sector, we then assessed an area factor for those TCS areas and assigned them their object-specific heat demand $\left(\mathrm{GWh}_{\mathrm{th}} / \mathrm{a}\right)$ and heat density $\left(\mathrm{kWh}_{\mathrm{th}} / \mathrm{m}^{2} \mathrm{a}\right)$.

The quality of the DLM dataset varies strongly for objects within object type 2112. Only the federal states of Brandenburg, Berlin, Saarland and Hamburg provide detailed information about how an area is actually used, e.g., for industrial purposes or for commercial functions like trade or storage. We were only able to distinguish between the heat demand for the industrial sector and the TCS sector in these states. Since no distinction could be made in the other states, we used the combined heat demand of the industrial and the TCS sector to model the heat demand of TCS areas.

\section{Large individual heat consumers}

We identified four categories of LIHC which are particularly suited for DHNs fueled by heat generated from biomass: schools, hospitals, public outdoor swimming pools, and commercial greenhouses [26]. For the categories "schools" and "hospitals," we used the POI-Bund Dataset which contains both spatial and content-related information on schools and hospitals such as the number of students per school or the number of beds per hospital [23].

For the category "public outdoor swimming pools," we used the DLM which contains outdoor swimming pools (object type 2345). The values for heat demand per square meter of water surface vary in the literature between $280 \mathrm{kWh}$ th $/ \mathrm{m}^{2} \mathrm{a}$ and $700 \mathrm{kWh}$ th $/ \mathrm{m}^{2} \mathrm{a}[36,37]$. In order to define an appropriate value for our model, we evaluated municipal energy reports on ten public outdoor swimming pools and used the mean value of $435^{6}$ $\mathrm{kWh}_{\mathrm{th}} / \mathrm{m}^{2} \mathrm{a}$.

The spatial information for the category "greenhouses" has been extracted from the OpenStreetMap buildings dataset. As this dataset does not contain any information on whether a greenhouse is used commercially, we have set the threshold of $100 \mathrm{~m}^{2}$ floor space ${ }^{7}$ as an indicator for this.

The heat demand for each object of those four categories was determined on the basis of object-specific key figures and object-specific reference units. Those key figures and their respective reference units are

\footnotetext{
${ }^{6}$ For the original values see [38-45]

${ }^{7} \mathrm{We}$ assumed that the floor space of privately used greenhouses does not exceed $100 \mathrm{~m}^{2}$.
} 
Table 2 Heat demand key figures of large individual heat consumers

\begin{tabular}{|c|c|c|c|c|}
\hline Type & Count & $\begin{array}{l}\text { Reference units } \\
\text { for heat demand }\end{array}$ & $\begin{array}{l}\text { Heat demand } \\
\left(\mathrm{kWh}_{\mathrm{th}} / \text { reference unit*a) }^{*}\right.\end{array}$ & Comment \\
\hline $\begin{array}{l}\text { Schools and } \\
\text { vocational colleges }\end{array}$ & 33,577 & No. of students & $\varnothing 542[46]$ & $\begin{array}{l}\text { The data on the number of students is incomplete for } 4220 \text { objects. In such } \\
\text { cases, we used the median heat demand of all schools: } 0.116 \mathrm{GWh}_{\mathrm{th}} / \mathrm{a}\end{array}$ \\
\hline Hospitals & 2217 & No. of beds & $\varnothing 27,320[46]$ & $\begin{array}{l}\text { The data on the number of beds is incomplete for } 413 \text { objects. In such } \\
\text { cases, we used the median heat demand of all hospitals: } 4.99 \mathrm{GWh} \text { th } / \text { a }\end{array}$ \\
\hline $\begin{array}{l}\text { Public outdoor } \\
\text { swimming pools }\end{array}$ & 4803 & $\mathrm{~m}^{2}$ water surface & $\varnothing 435$ & $\begin{array}{l}\text { Value for heat demand is taken from municipal energy reports on heat } \\
\text { demand of public outdoor swimming pools }\end{array}$ \\
\hline $\begin{array}{l}\text { Commercial } \\
\text { greenhouses }\end{array}$ & 14,868 & $m^{2}$ & $\varnothing 103[47]$ & Minimum floor space of $100 \mathrm{~m}^{2}$ \\
\hline
\end{tabular}

shown in Table 2. This enabled us to model the heat demand for a total of 55,465 individual objects.

\section{Assessment of the BEP-specific heat sales potential}

To determine the BEP-specific heat supply potentials, we looked at two different options on how BEPs can feed heat into a potential DHN. The spatial and technical information needed to do this was taken from the DBFZ bioenergy plant database. This database is continuously updated and contains detailed information on BEPs in Germany. It is based on information which the Federal Network Agency (Bundesnetzagentur, BNetzA) publishes on BEPs as part of the German Renewable Energy Act (Erneuerbare Energien Gesetz (EEG)) remuneration scheme and explained in more detail in Scheftelowitz et al. [18]. It is not possible to derive from the data whether a BEP already feeds into a DHN or not. For the following analyses, this aspect is not taken into consideration. It is also not possible to determine from the BEP database whether a BEP is actually a production unit or if it is a satellite CHPU which cannot be operated independently of its production unit. For this reason, all investigated BEPs are considered to be production units, an assumption which distorts the actual situation.

\section{Distance-related heat supply scenarios}

To determine the plant-specific tHSP, we looked at two different design options for DHNs: A and B. These are defined as follows: in Option A the heat produced at the BEP site is transported to the consumers via a directly connected local heating network, whereas in Option B biogas is transported via a raw biogas pipeline to a CHPU located directly on the site of the heat sink and the DHN commences at this point. Since the way heat is transported in Option A involves losses of up to $10 \%$, the heat sink must be located in the immediate vicinity of the BEP [48]. The minimum overall heat density for a DHN in year-round operation is defined by the Quality Management (QM) system of the German/Swiss initiative "QM Holzheizwerke" as being $2 \mathrm{MWh} /$ line meter and year [48]. In a comparable calculation for a region in Rhineland-Palatinate made in 2010, IZES and the
Institut für Energie- und Umweltforschung (ifeu) [49] stated that there should be a heat sink within a radius of $1000 \mathrm{~m}$ around a BEP to reach this value. Daniel et al. [50] found a higher figure for the whole grid and concluded that losses must not exceed $20 \%$ to ensure sufficient profitability. Losses up to this value occur with total grid lengths of between $1000 \mathrm{~m}$ and $5000 \mathrm{~m}$ and depend on the capacity of the respective CHPU [50]. Taking this assumption into account, we defined for our model a maximum distance of $1500 \mathrm{~m}$ between the BEP and the heat sink. This option is applicable for all BEPs.

Option B is applicable for biogas plants only. Since biogas can be transported over longer distances with only minor losses, the distance between the heat source and heat sink can be greater for this option. Obviously, this distance depends again on the capacity of the installation. IZES and ifeu [49] reported that BEPs with an installed capacity of $500 \mathrm{~kW}_{\mathrm{el}}$ can reach a distance of up to $5000 \mathrm{~m}$ for raw biogas pipelines without losing their economic feasibility [49]. In our case, we followed the assumption of this maximum distance between BEP and heat sink $(5000 \mathrm{~m})$ even though the mean value of the installed capacity of biogas plants throughout Germany is only $435 \mathrm{~kW}_{\mathrm{el}}$ [51]. A visual illustration of the two options for district heating networks under consideration is provided in Fig. 2.

To identify the plant-specific heat sales potential, we then used the spatial information on BEPs from the DBFZ bioenergy plant database and conducted a spatial query into whether there are suitable heat sinks at the respective distances. For residential areas and TCS areas, we defined that the minimum heat density ${ }^{8}$ of the nearest heat sink has to be higher than $50 \mathrm{kWh} \mathrm{th} / \mathrm{m}^{2} \times \mathrm{a}^{9}$ in order to be suitable for the DHN design options presented above. For the LIHCs, we did not define such a precondition, but instead considered the total heat demand of the respective LIHC.

\footnotetext{
${ }^{8}$ Heat density is a function of the area $\left(\mathrm{m}^{2}\right)$ of a heat sink and its annual heat demand in $\mathrm{kWh}$ th.

${ }^{9} 50 \mathrm{kWh} / \mathrm{m}^{2} \mathrm{a}$ can be regarded as the minimum heat density required for a local heating network [52].
} 

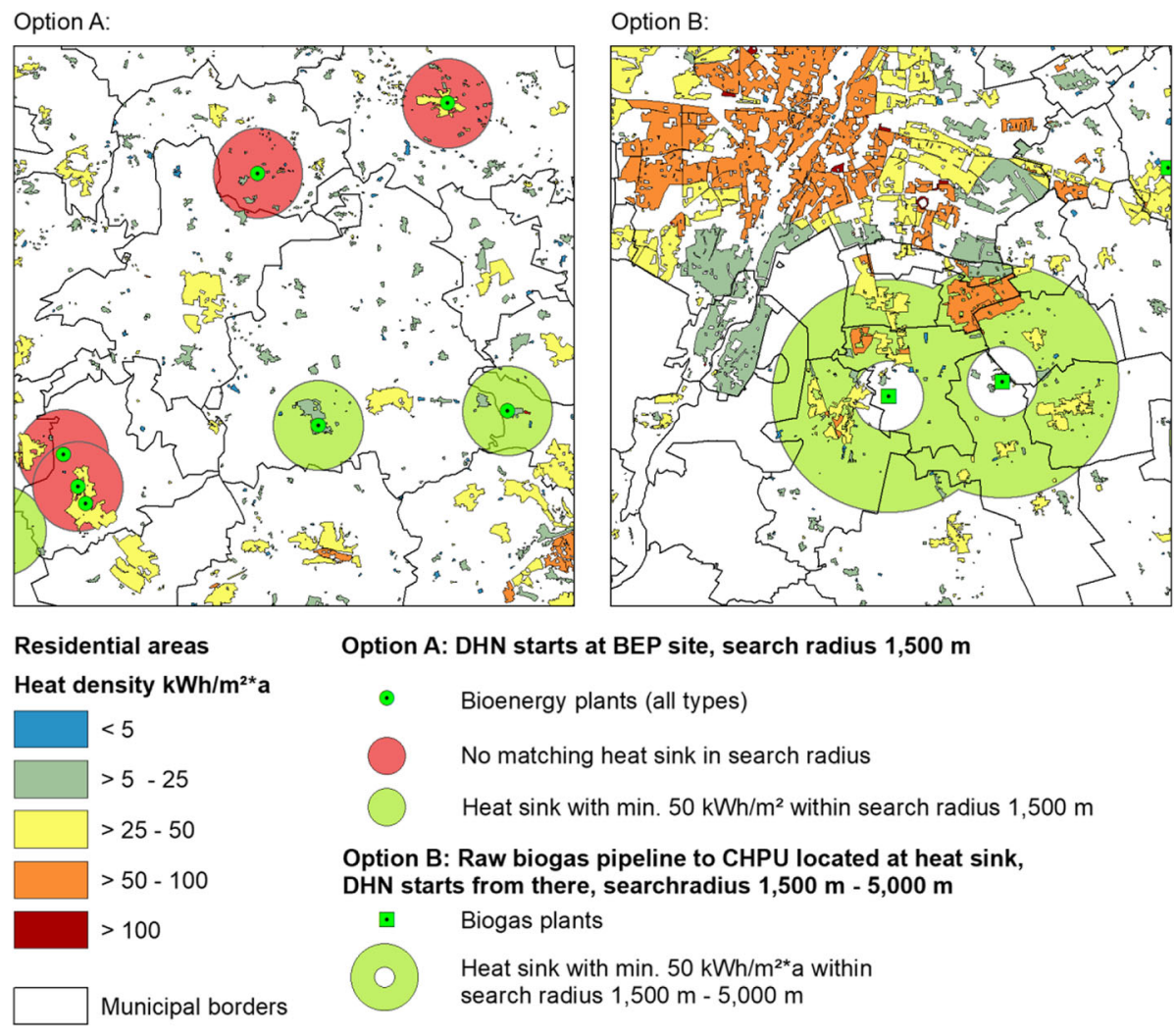

Option A: DHN starts at BEP site, search radius $1,500 \mathrm{~m}$

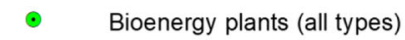

No matching heat sink in search radius

Heat sink with min. $50 \mathrm{kWh} / \mathrm{m}^{2}$ within search radius $1,500 \mathrm{~m}$

Option B: Raw biogas pipeline to CHPU located at heat sink, DHN starts from there, searchradius $1,500 \mathrm{~m}-5,000 \mathrm{~m}$

- Biogas plants

Heat sink with min. $50 \mathrm{kWh} / \mathrm{m}^{2 *}$ a within

search radius $1,500 m-5,000 m$

\begin{abstract}
Data basis: IZES / Wuppertal Institut / Fraunhofer UMSICHT 2015 (data modified), (C) Statistisches Bundesamt 2015, DBFZ 2018

Map basis: (C) GeoBasis-DE / BKG 2012 (data modified)

Cartography: Michael Steubing (UFZ) 2018
\end{abstract}

Fig. 2 District network options for bioenergy plants

\section{Categorizing the heat supply potential using line density modeling}

So far in the spatial modeling approach, all heat sinks with a corresponding heat density of $50 \mathrm{kWh}$ th $/ \mathrm{m}^{2} \mathrm{a}$ in the vicinity of the respective BEP are initially selected as potential heat sinks. However, the gross heat demand (in $\mathrm{GWh}_{\text {th }} / \mathrm{a}$ ) of the heat sink can be insufficient for achieving an economically viable DHN. Therefore, the spatial model required enhancement. To do this, we introduced the line density factor $L D F$. This factor represents the ratio of the heat demand of a heat sink in relation to the total potential network length and the funding conditions of the German Kreditanstalt für Wiederaufbau (KfW) for DHNs in Germany ${ }^{10}$ and was calculated as follows:

\footnotetext{
${ }^{10}$ The German Kreditanstalt für Wiederaufbau (KfW) is Germany's largest development bank and grants loans to construct DHNs. In return, the bank demands a minimum yearly heat turnover of 500 $\mathrm{kWh}_{\mathrm{th}} / \mathrm{a}$ per line meter [53].
}

$$
L D F=\left(\frac{Q_{R A O}}{D \times N L F}\right) \times 500 \mathrm{kWh} / \mathrm{a}
$$

where LDF is the line density factor, $\mathrm{Q}$ is the heat demand $\left(\mathrm{kWh}_{\mathrm{th}} / \mathrm{a}\right), \mathrm{D}$ is the linear distance bioenergy plant-heat sink (m), NLF is the network length factor, and RAO is the residential area object.

We assumed that if the annual heat demand of a given heat sink was unable to generate the required heat turnover of $500 \mathrm{kWh}_{\text {th }}$ per line meter [53], it was highly unlikely that a DHN would be built. This much more simplified method is a suitable way to eliminate inadequate heat sinks from the model. Values for a line density factor below 1 indicate that the annual heat turnover of a potential DHN would be too low. All heat sinks with a line density factor $<1$ were therefore excluded from the model, which subsequently only contained heat sinks suitable for DHNs.

In order to determine the line density factor, it is necessary to know the total length of the DHN. Within the GIS model, however, only linear distances from the heat 


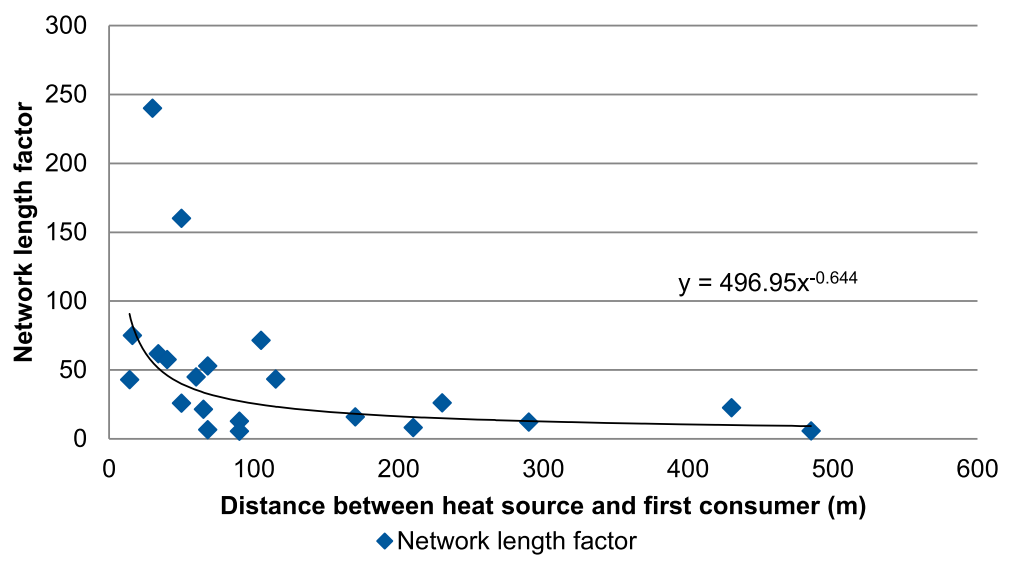

Fig. 3 Network length factor for twenty biomass-fueled district heating networks

source to the potential first consumer are known. The total network length must be estimated. For this purpose, we introduced the network length factor NLF. It describes the ratio of the total network length of a DHN to the distance between the heat source (the BEP) and the initial heat consumer and was calculated using Formula 7.

$$
N L F=\frac{L_{\text {tot }}}{D}
$$

where NLF is the network length factor, $L_{\text {tot.. }}$ is the total network length $(\mathrm{m})$, and $\mathrm{D}$ is the linear distance bioenergy plant to heat sink (m).

The NLF had to be assessed empirically. For this purpose, we analyzed 20 existing biomass-fueled DHNs for which the total network length is known [54-67]. We measured the distance between the heat-generating plant and the potential first consumer of these DHNs and calculated the NLF. Our data on the respective DHNs only includes cases where the distance between the plant and the first consumer is less than $500 \mathrm{~m}$. For these systems, the median value of the NLF is 26.1. ${ }^{11}$ For systems where there is a distance $>500 \mathrm{~m}$ between the heat source and the initial consumer, which occurs in our GIS data, the NLF was determined with the corresponding degression (see Fig. 3).

Figure 4 illustrates the correction process described above. If heat sink 1 is located within the search radius of $1500 \mathrm{~m}$ around a BEP and has a heat demand of 1.9 $\mathrm{GWh}_{\text {th }} / \mathrm{a}$ then, to develop the area, the heating network would have to be $6500 \mathrm{~m}$ long (assumption). However, to receive financial support, an annual heat turnover of at least $3.25 \mathrm{GWh}_{\text {th }}\left(6500 \mathrm{~m} \times 500 \mathrm{kWh}_{\text {th }} / \mathrm{a}=3,250,000\right.$ $\left.\mathrm{kWh}_{\mathrm{th}} / \mathrm{m} \times \mathrm{a}\right)$ is required. Heat sink 1 does not have a

\footnotetext{
${ }^{11}$ The original values for the total network length, the linear distance from the BEP to the potential first heat customer and the resulting NLF can be found in Table 11 in the Appendix.
}

sufficient heat demand to operate the DHN economically and can therefore not be considered suitable for a local heating network (line density factor $<1$ ). Heat sinks 2 and 3, on the other hand, have a sufficient heat demand and can therefore be considered for a DHN (line density factor $>1$ ).

\section{Economic viability of heat sales potential}

This section presents the methodology used for assessing the economic heat sales potential (eHSP), since a second objective of this study was to evaluate the economic viability of the specific heat supply potential of the current German BEP stock. Here, the same dataset for BEPs was used as shown in Table 1.

Even though this study aimed to gain initial insights into the market potential of heat as a by-product of electricity generation, a full techno-economic feasibility assessment was not within the scope of our study. In our approach, economic viability depends on the potential of heat sales (demand/supply) and the associated estimated costs for heat distribution infrastructure (pipelines, peak load boilers, and storage facilities) as well as the earnings from heat sales.

\section{Evaluation scheme and main assumptions}

In order to assess the eHSP, we developed an evaluation scheme that consisted of four main steps (Fig. 5). We first established individual BEP-heat sink relationships (Step 1) and then derived relevant indicators based on plant-specific data (Step 2). Before transferring all the information onto a bigger scale (Step 3), we grouped all the individual BEPs into clusters according to their EEG remuneration key. This enabled us to obtain the desired overview of the German BEP stock without compromising plant-specific data and provided the basis for the final economic assessment (Step 4).

In addition to the information on location and the related potential heat demand from spatial heat demand 


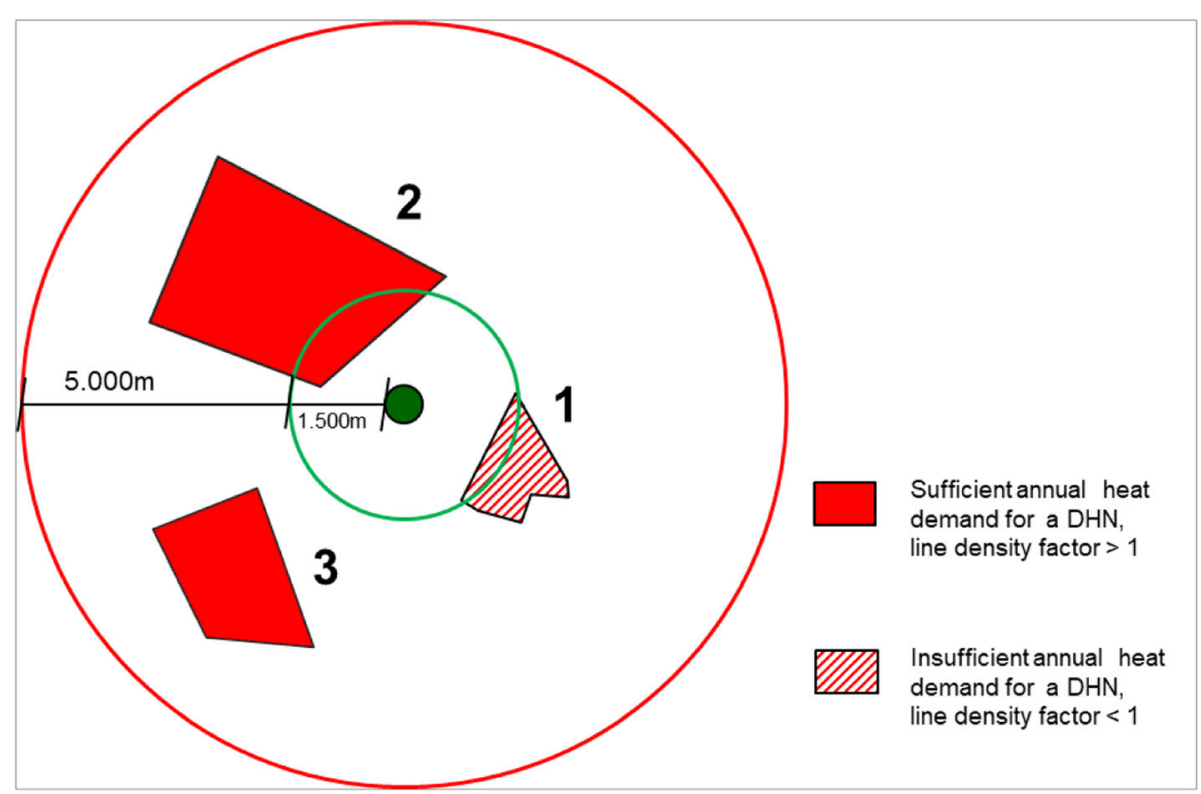

Fig. 4 Illustration of the model correction using the line density factor

modeling (see above), we used energy-related BEP inventory data (Table 3 ) obtained from two databases: publicly available data published by the German Federal Network Agency (BNetzA) and datasets retrieved from annual plant operator surveys by the DBFZ (see [51]).

In this approach, we assumed four factors to be determinant for the economic viability of heat sales from BEPs (Table 4). Whereas the distance between the heat sink and the BEP (1), the type of heat sink (2) and the heat supply-demand ratio (3) all govern the choice and size of the heat distribution infrastructure (pipelines, peak-load boilers, and storage facilities), the heat market price (4) ultimately determines income from heat sales. Other factors (e.g., local conditions underground which influence the excavation costs or regional differences between temperature profiles) may also have an influence on economic viability but their consideration would go far beyond the scope of this study.

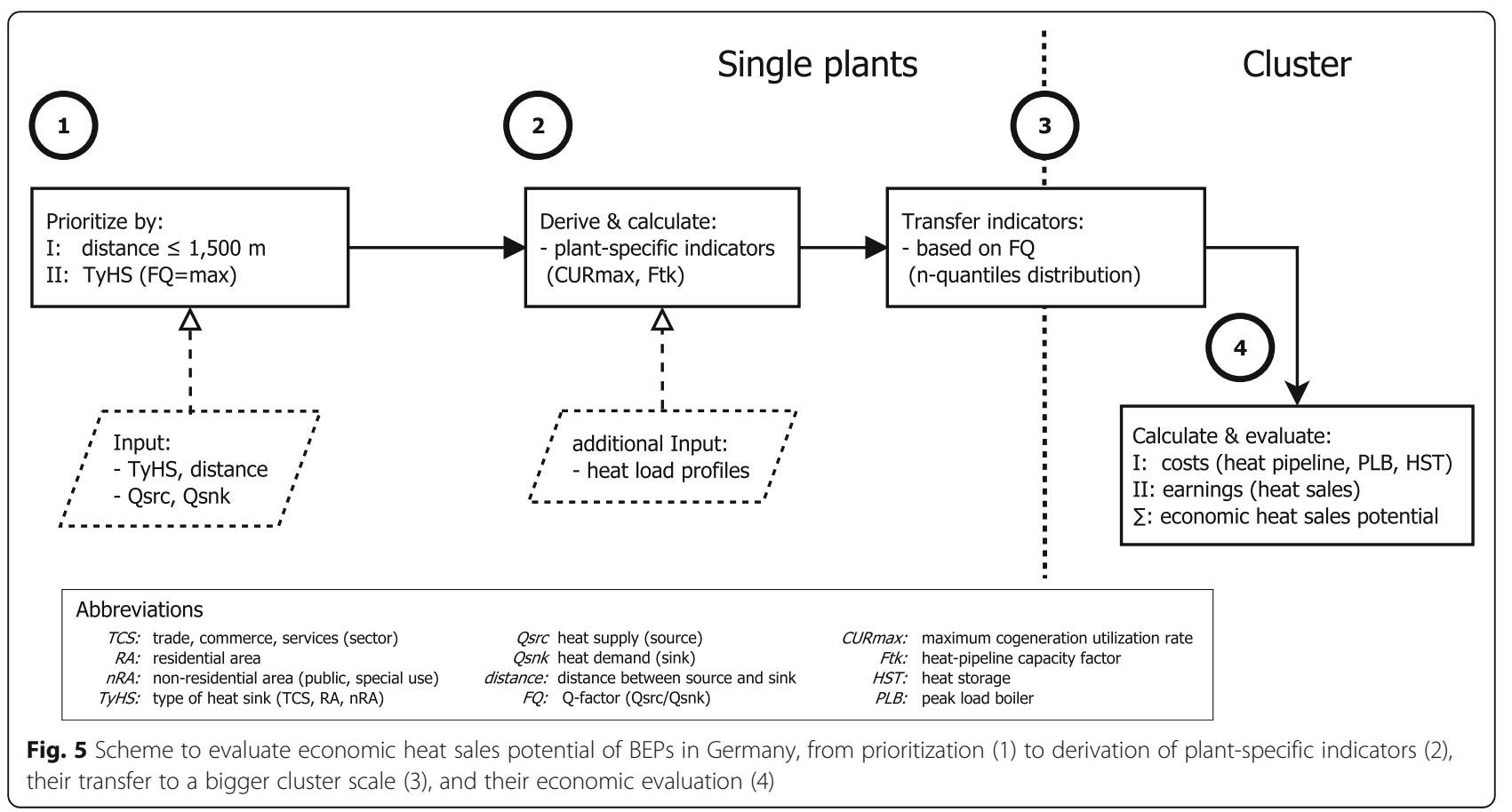


Table 3 Mean cluster-specific energy (supply) capacities based on BEP-specific values from German inventory data

\begin{tabular}{|c|c|c|c|c|c|c|}
\hline $\begin{array}{c}\text { Cluster } \\
\text { Unit }\end{array}$ & $\mathrm{n}$ & $\begin{array}{r}\text { Main-Group } \\
{[-]} \\
\end{array}$ & $\begin{array}{r}\text { inst. cap. (el) } \\
{[\mathrm{kW}]}\end{array}$ & $\begin{array}{r}\text { inst. cap. (th) } \\
{[\mathrm{kW}]}\end{array}$ & $\begin{array}{r}\text { gross heat p.a. } \\
{[\mathrm{MWh}]}\end{array}$ & $\begin{array}{r}\text { net heat p.a. } \\
{[\mathrm{MWh}]}\end{array}$ \\
\hline biogas plant - slurry $75 \mathrm{~kW}$ & 1 & \multirow{2}{*}{$\begin{array}{r}\text { biogas } \\
\text { (slurry) }\end{array}$} & 70 & 88 & 672 & 403 \\
\hline biogas plant - (slurry) 150kW* & 2 & & 115 & 138 & 866 & 598 \\
\hline biogas plant - energy crops $250 \mathrm{~kW}$ & 3 & \multirow{4}{*}{$\begin{array}{r}\text { biogas } \\
\text { (energy crops) }\end{array}$} & 215 & 244 & 1,712 & 1,181 \\
\hline biogas plant - energy crops 500kW & 4 & & 493 & 544 & 3,854 & 2,698 \\
\hline biogas plant - energy crops $750 \mathrm{~kW}$ & 5 & & 726 & 763 & 4,737 & 3,363 \\
\hline biogas plant - energy crops $1,000 \mathrm{~kW}$ & 6 & & 1,315 & 1,315 & 5,927 & 4,446 \\
\hline biogas plant - residues $750 \mathrm{~kW}$ & 7 & \multirow{3}{*}{$\begin{array}{r}\text { biogas } \\
\text { (residues) }\end{array}$} & 461 & 484 & 1,976 & 1,502 \\
\hline biogas plant - residues $1,000 \mathrm{~kW}$ & 8 & & 1,140 & 1,140 & 4,607 & 3,455 \\
\hline biogas plant - residues $2,000 \mathrm{~kW}$ & 9 & & 1,500 & 1,427 & 5,779 & 4,276 \\
\hline waste wood power plant $10,000 \mathrm{~kW}$ & 10 & CHP (waste wood) & 11,727 & 27,469 & 172,678 & 172,678 \\
\hline wood powered CHP 50kW & 11 & \multirow{5}{*}{$\mathrm{CHP}$ (wood) } & 39 & 94 & 376 & 376 \\
\hline wood powered CHP $250 \mathrm{~kW}$ & 12 & & 270 & 559 & 2,533 & 2,533 \\
\hline wood powered CHP 2,000kW & 13 & & 1,384 & 4,568 & 21,928 & 21,928 \\
\hline wood powered CHP 5,000kW & 14 & & 5,233 & 12,558 & 69,737 & 69,737 \\
\hline wood powered CHP 10,000kW & 15 & & 11,889 & 21,796 & 117,207 & 117,207 \\
\hline wood powered CHP 20,000kW & 16 & CHP (paper pulp) & 30,216 & 26,275 & 117,941 & 117,941 \\
\hline vegetable oil CHP 250kW & 17 & CHP (vegetable oil) & 124 & 140 & 337 & 337 \\
\hline biomethane CHP 50kW & 18 & \multirow{3}{*}{ CHP (biomethane) } & 33 & 59 & 205 & 205 \\
\hline biomethane CHP 250kW & 19 & & 272 & 299 & 1,482 & 1,482 \\
\hline biomethane CHP 1,000kW & 20 & & 1,192 & 1,250 & 5,829 & 5,829 \\
\hline
\end{tabular}

Net heat production is taking auxiliary power requirements into consideration

${ }^{*}$ Cluster 2 does not solely use slurry but a mix of different substrates

\section{Steps 1-3: assessment indicators}

In the first step of this evaluation scheme (Fig. 5), we used the spatial and energy-related information (derived from the above presented assessment of tHSP) to establish single BEP-heat sink relationships. We assumed specific heat delivery costs would decrease (economies of scale) as potential heat demand increased. Therefore, we linked each BEP to a single heat sink within a radius of $1500 \mathrm{~m}$ (Option A of the DHN design options) that had the highest potential heat demand (see Fig. 4 for an illustration). Since we expected that heat distribution costs would significantly affect economic viability, we excluded the option of exploring a larger radius or possible connections between multiple producers and consumers We deliberately excluded biogas plants with potential heat sinks within a radius of 1500-5000 m and the construction of a raw biogas pipeline from this assessment (Option B of the previously described DHN design options). Also, our methodology is only suitable for a $1: 1$ ratio between BEP and heat sinks, so we were unable to incorporate cross-linked networks.

We operationalized the BEP-heat sink relationship by introducing the "Q-factor" (FQ) which is heat demand $\left(Q_{\text {snk }}\right)$ divided by net heat production $\left(Q_{\text {src }}\right)$ (Formula 8$)$. Furthermore, we decided to use this indicator as a main reference point for the economic assessment.

$$
\mathrm{FQ}=\frac{Q_{\text {snk }}}{Q_{\text {src }}}
$$

Table 4 Key determinants for assessing the economic feasibility of BEP heat sales potential (eHSP)

\begin{tabular}{|c|c|c|}
\hline \multicolumn{2}{|c|}{ Determinants } & \multirow{2}{*}{$\begin{array}{l}\text { Effects on the BEP heat sales potential } \\
\text { The distance between a BEP and a potential heat sink determines the required length of heat pipelines } \\
\text { (investment costs). }\end{array}$} \\
\hline 1 & Location (distance) & \\
\hline 2 & Type of heat sink (TyHS) & $\begin{array}{l}\text { Seasonal fluctuations and peaks in the heat demand vary depending on the type of heat sink (heat load profiles). } \\
\text { Peaks and troughs in heat demand might justify the use of peak load boilers (PLB) and heat storage facilities (HST). }\end{array}$ \\
\hline 3 & $\begin{array}{l}\text { Heat supply-demand ratio } \\
(F Q)\end{array}$ & $\begin{array}{l}\text { Heat distribution infrastructure needs to fit the given supply-demand ratio (transmission capacity) which also deter- } \\
\text { mines the potential earnings from heat sales. }\end{array}$ \\
\hline 4 & $\begin{array}{l}\text { Heat price at the point of } \\
\text { sale }\left(C_{\text {h@POS }}\right)\end{array}$ & $\begin{array}{l}\text { The additional income expected from heat sales depends not only on the distribution costs but also on the } \\
\text { market price for heat. }\end{array}$ \\
\hline
\end{tabular}


Table 5 Construction of synthetic heat load profiles

\begin{tabular}{lll}
\hline Type of heat sink & Type of heat load profile & Description \\
\hline Residential sector & "Single dwelling", see [68] & Used for settlements \\
TCS/industrial sector & Weighted average of 10 TCS-load profiles from [68] & Used for TCS heat sinks as a blend of different TyHS \\
LIHC & "Laundry", see [68] & Used for LIHC like public outdoor swimming pools, \\
& greenhouses, schools, and hospitals \\
\hline
\end{tabular}

where FQ is the heat source-sink-ratio, $Q_{\text {snk }}$ is the heat demand of a heat sink $\left(G W h_{\text {th }} / \mathrm{a}\right)$, and $Q_{\text {src }}$ is the net heat production of BEP $\left(\mathrm{GWh}_{\mathrm{th}} / \mathrm{a}\right)$.

To refine this assessment, we considered seasonal fluctuation in heat demand depending on the characteristics of the type of heat sink (TyHS). Here, we distinguished between three TyHS for which we created synthetic heat load profiles according to a methodology that was presented by [68] (Table 5). For reasons of simplicity, we allocated the annual heat demand over the course of a year $(8760 \mathrm{~h})$ and decided not to create regionally explicit heat load profiles but to use only one climate reference dataset (weather station in Potsdam [69]).

In the second step of the evaluation scheme (Fig. 5), we extended the plant-specific data and derived other indicators that influence the economic viability of heat sales, i.e., the maximum cogeneration utilization rate $\left(\mathrm{CUR}_{\max }\right)$ and a heat pipe capacity factor $\left(F_{\mathrm{tk}}\right)$.

The maximum cogeneration utilization rate $\left(\mathrm{CUR}_{\max }\right)$ indicates how much of the BEP's gross heat generation could be sold on the market, taking into account a seasonal fluctuation in heat demand. For reasons of simplicity, we do not consider flexible operation of BEPs but assume 24-h operations that result in a constant heat supply at full capacity (net heat production) throughout the year. When both power and heat have to be considered at a temporal resolution, the analysis becomes much more complex. We focused on varying heat demands and used heat load profiles, we had generated previously (Table 5) to calculate the $\mathrm{CUR}_{\max }$ for each TyHS and for the FQ at intervals of 0.1 until a CUR $\max$ of nearly $100 \%$ was reached (see Fig. 6).

Furthermore, we assumed that the investment costs of heat pipelines depend not only on their length but also on their diameter (heat transmission capacity). When heat storage facilities (HST) and bio-fueled peak load boilers (PLB) were used to supplement cogeneration and maintain heat supply, we also needed to adjust the heat pipeline diameter accordingly. Therefore, we introduced a heat pipe capacity factor $\left(F_{\mathrm{tk}}\right)$, defined as the ratio of net heat supply to annual peak loads as observed in the generated load profiles (Table 5).

In the third step of the evaluation scheme (Fig. 5), we transferred the single-source sink-related data to the cluster level by aggregating the previously gathered information $\left(\mathrm{FQ}, \mathrm{CUR}_{\max }, F_{\mathrm{tk}}\right)$ and the cluster-related information (Table 3). To do this, we divided each cluster into five groups each of which represented $20 \%$ of the BEPs in the respective cluster (quintiles) and which referred to equally sized classes of FQ. The FQ values assigned to each previous BEP-heat sink pair (Formula 8 ) were used for this statistical division. Whereas quintile 1 represents the $20 \%$ of BEPs with the smallest FQ values, quintile 5 represents the 20\% of BEPs with the

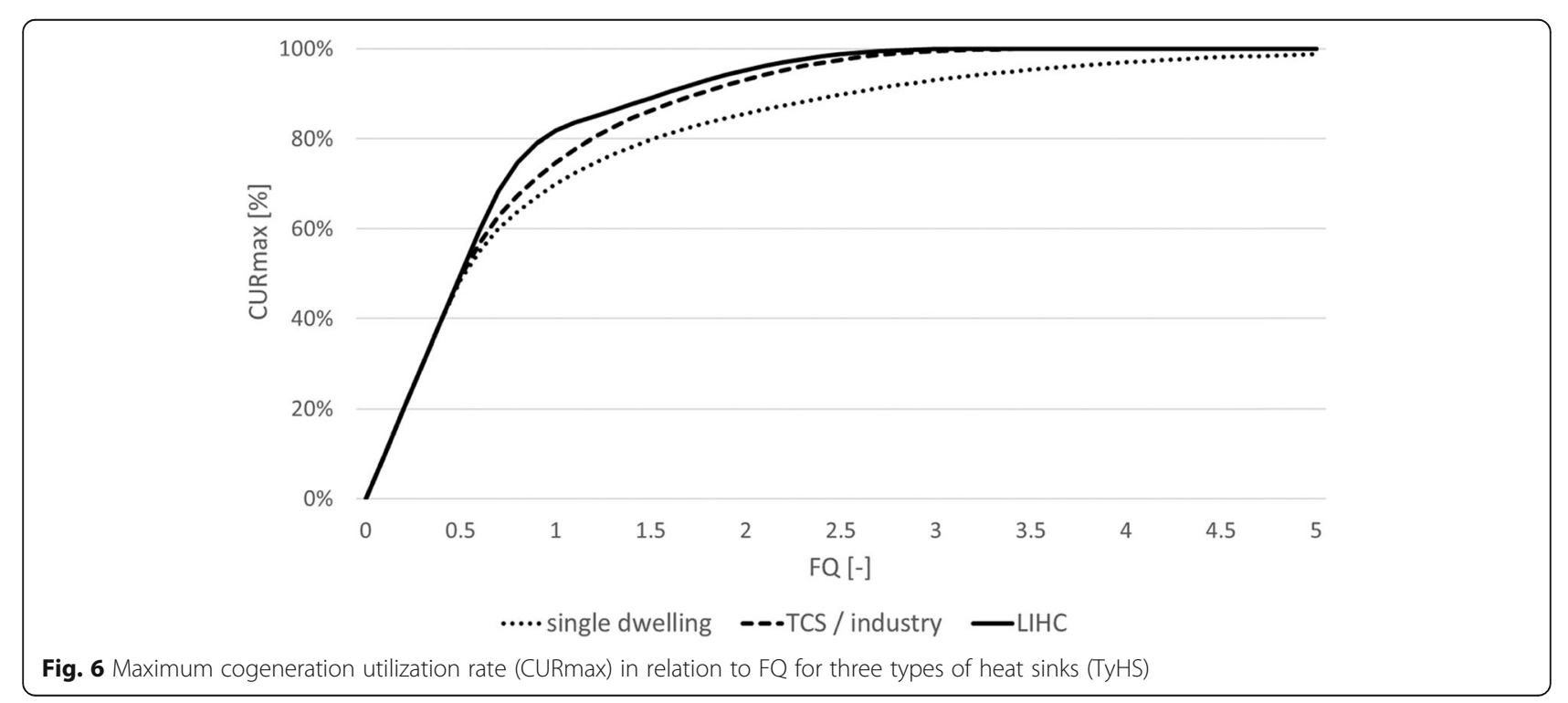


largest FQ values. Using this approach, we then assigned each BEP-heat sink pair to a cluster quintile and calculated the arithmetic mean of the $\mathrm{CUR}_{\max }$ and $F_{\mathrm{tk}}$.

\section{Step 4: economic assessment}

In the fourth and final step of the evaluation scheme (Fig. 5), we assessed the economic heat sales potential (eHSP) of German BEPs for all cluster quintiles based on the previously generated dataset. The remainder of this section will describe how we calculated the capital expenditures (CAPEX) for the heat distribution infrastructure and how we related these costs to expected earnings from heat sales.

The CAPEX in this assessment included investment costs such as annuities for heat pipelines, peak load boilers (PLB), and heat storage facilities (HST). For all cost calculations, we fixed the interest rate at 5\% and assumed no price increase during a depreciation period of 15 years for PLBs and HSTs, and 25 years for heat pipelines. As a requirement for heat sales from BEPs, we first calculated the CAPEX for heat pipelines for all BEP-heat sink pairs. Then, we defined the PLBs and HSTs to those pairs that fulfilled a specific set of criteria (Table 6) and calculated the additional CAPEX from using them (including fuel costs for PLB). Finally, we calculated the mean CAPEX for each BEP cluster quintile and added the expected earnings from heat sales. Hence, we determined the economic viability of heat sales from German BEPs, including additional earnings from using PLBs and HSTs.

To calculate the CAPEX for heat pipelines $\left(C_{\text {pipe }}\right)$, we derived specific pipeline costs and multiplied them by the length of the heat pipelines required to connect each BEP with a heat sink (Formula 9). We introduced a correction factor $(\mathrm{CF})$ to account for the fact that a heat pipeline will need to deviate from a direct line in order to overcome infrastructural barriers like residential areas, roads, or rail lines. We multiplied this CF by the distance between each BEP and heat sink to derive the required pipeline length (Formula 9). However, we did not consider the local distribution and transmission infrastructure that would be required, e.g., for district heating in residential areas [70].

$$
L_{\mathrm{T}}=D \times C F
$$

where $L_{\mathrm{T}}$ is the length of a heat pipeline that is equal to the distance between a BEP-heat sink pair (Step 1,
Fig. 5) multiplied by a correction factor (CF). CF is equal to the square root of 2 which results from applying the Pythagorean theorem. Streamlining deviations, we divided the alternative way (the sum of the two legs of a right-angled triangle) by the direct distance between the BEP and heat sink (hypotenuse).

$$
C_{\text {pipe }}=\left(C_{\mathrm{T}}+C_{\mathrm{c}}\right) \times L_{\mathrm{T}}
$$

where $C_{\text {pipe }}$ is the cost of the heat pipeline calculated for each BEP-heat sink pair (Step 1, Fig. 5). $C_{T}$ is the cost of the heat pipelines per meter (as a function of $\mathrm{P}_{\text {th }}$ and $\left.\mathrm{F}_{\mathrm{tk}}\right) . \mathrm{C}_{\mathrm{c}}$ represents other construction-related costs per meter (underground work and planning), and $L_{\mathrm{T}}$ is the length of heat pipeline $(\mathrm{m})$.

Serving peak loads or storing heat in times of low demand might be economically reasonable if the expected additional earnings outweigh the additional CAPEX for HSTs and PLBs (including fuel costs for a PLB). Furthermore, the use of HSTs and PLBs would have an impact on the CAPEX for heat pipelines, affecting the required heat transmission capacity (diameter). We therefore established a set of rules for three different heat marketing concepts based on the level of FQ (Table 6). According to these rules, we decided whether to use peak load boilers (PLB) and/or heat storage (HST) for each BEPheat sink pair and adjusted the required heat pipeline capacity accordingly.

Following a "full supply" marketing concept, we used HST and PLB and placed them close to the source (here the BEP). By adapting the pipeline capacity, all peak loads of heat could be potentially served via the heat pipeline $\left(F_{t k} \times \mathrm{P}_{t h}\right)$. The "basic supply" marketing concept differs as it prescribes only the use of an HST. Due to periods of peak demand, heat pipelines should be able to transport heat produced by the BEP and discharge the capacity of the storage. We therefore proposed that a heat pipeline's capacity should be double the value of the BEP's thermal capacity $\left(F_{\mathrm{tk}}=2\right)$ while both the charge and discharge rates are equal to the BEP heat capacity. The "full feed-in" option assumes there is no need for a PLB or HST so that we based the transmission capacity of the pipelines solely to the BEP's capacity $\left(F_{\mathrm{tk}}=1\right)$.

In addition to considering the use of PLB and HST for the "full supply" and "basic supply" concepts, we

Table 6 Rules for deciding on the heat sales marketing concept based on the FQ

\begin{tabular}{rrccc}
\hline Range of Q-factors & $\mathrm{FQ} \leq 1.5$ & $1.5<\mathrm{FQ} \leq 5$ & $\mathrm{FQ}>5$ \\
\hline marketing concept & full supply & basic supply & full feed-in \\
heat storage facility & yes & yes & no \\
peak load boiler & yes & no & no \\
heat pipeline capacity & Qsnk & $2 *$ Qsrc & Qsrc \\
\hline
\end{tabular}


optimized their size aiming to find the most costefficient combination of both. For this purpose, we used a cost function (Formula 12) that builds upon an optimization approach which suggests that the investment costs for HST and PLB depend on their volume and power capacity [71].

The optimization approach for an ideal combination of PLB and HST is described in [71]. Here, we only accounted for the different heat load profiles for each quintile in every cluster (based on the previous TyHS and $\mathrm{CUR}_{\max }$ ) in order to find minimum overall costs.

$$
C_{\text {opt. }}=f(V)+f(P)+\left(C_{\text {fuel }}-C_{\text {h@POS }}\right) \times P_{t h} \rightarrow \min
$$

where $C_{\text {opt. }}$ is the cost optimum, $\mathrm{f}(\mathrm{V})$ and $\mathrm{f}(\mathrm{P})$ are functions of the CAPEX for HSTs and PLBs [71] and $P_{\text {th }}$ is a cluster's power capacity (see Table 3 ), $C_{\text {fuel }}$ represents fuel costs and $C_{\mathrm{h} @ \mathrm{POS}}$ is the heat price at the point of sale. For simplification purposes, we fixed the potential heat losses from heat storage at a value of $10 \%$, the PLB efficiency $(\eta)$ at $85 \%$, the $C_{\mathrm{h} @ \mathrm{POS}}$ at $50 € / \mathrm{MWh}_{\text {th }}$ and the $\mathrm{C}_{\text {fuel }}$ at $30 € / \mathrm{MWh}_{\text {th }}$.

We are aware of the fact that we created an inherent incentive to use PLB $\left(C_{h @ P O S}>C_{f u e l}\right)$ and real prices for heat would be influenced by many factors such as the locality, market characteristics, and the type of heat sink. For instance, factors that affect local demand for heat from BEPs include existing access to the gas grid, availability (and abundance) of solid biogenic fuel (from wood), and a fossil-fueled heat source that is already connected to existing heat pipelines. However, due to the scope of this study, we did not specify and adjust the calculations to these factors. Finally, we determined the economic heat sales potential (eHSP) from German BEPs for all the cluster quintiles by calculating the annual heat sales potential in terms of heat earnings $\left(E_{\text {sale }}\right)$ (Formula 13) minus the financial expenditure for heat distribution (PLB, HST, and heat pipelines) (Formula 14).

$$
E_{\text {sale }}=C_{\text {h@POS }} \times W_{\text {th }} \times \mathrm{CUR}_{\max }
$$

where $E_{\text {sale }}$ is the annual heat earnings $(€), C h_{@ P O S}$ is the price of heat at the point of sale fixed at 50 $€ / \mathrm{MWh}_{\text {th }}, W_{\text {th }}$ is the net heat production (Table 3), and $\mathrm{CUR}_{\max }$ is the maximum cogeneration utilization rate for each BEP cluster quintile.

$$
\mathrm{eHSP}=E_{\text {sale }}-C_{\text {opt }}-C_{\text {pipe }}
$$

where eHSP is the economically viable heat sales potential, $E_{\text {sale }}$ is the annual heat earnings $(€), C_{\text {opt. }}$ is the cost optimum, and $C_{\text {pipe }}$ is the cost of heat pipeline from BEP to heat sink $(€)$.

Since we considered mainly heat as a by-product of electricity generation, we divided the eHSP (Formula 14) by the current electricity generated by the German BEP stock (as kWh of electrical power per BEP cluster [51]). This enabled us to compare the option of heat sales to other CHP options.

\section{Results}

The outcomes of this study can be divided into three categories. Firstly, the spatially explicit heat demands for different relevant sectors, secondly the heat sales potential of the BEPs as a whole and on a plant-by-plant basis, and finally the estimation of the valuable heat sales potential.

\section{Spatially explicit data on heat demand}

As a result of the previously described modeling process, spatially explicit data is now available on the heat demand of various types of heat sinks (residential, TCS and industrial, large individual heat consumers) at a submunicipal level for the whole of Germany. The data includes the type of heat sink (residential area objects, TCS/industrial area objects, LIHC), their gross heat demand in $\mathrm{GWh}_{\mathrm{th}} / \mathrm{a}$ and their heat density in $\mathrm{kWh}$ th $/ \mathrm{m}^{2} \mathrm{a}$.

\begin{tabular}{|c|c|c|c|c|c|c|c|c|}
\hline \multicolumn{9}{|l|}{ Residential area objects } \\
\hline \multirow[t]{2}{*}{ Heat density $\left(k W h_{t h} / m^{2} a\right)$} & \multirow[t]{2}{*}{$<5$} & \multirow[t]{2}{*}{$>5-25$} & \multirow[t]{2}{*}{$>25-50$} & \multirow[t]{2}{*}{$>50-100$} & \multirow[t]{2}{*}{$>100$} & \multirow[t]{2}{*}{ Total } & \multicolumn{2}{|c|}{$\begin{array}{l}\text { Potential suitability for DHN } \\
\left(>50 \mathrm{kWh} \mathrm{th}_{\mathrm{th}} / \mathrm{m}^{2} \mathrm{a}\right)\end{array}$} \\
\hline & & & & & & & Count & $\%$ \\
\hline No. of objects in class & 93,738 & 327,011 & 107,322 & 25,718 & 12,669 & 566,458 & 38,387 & 6.8 \\
\hline \multicolumn{9}{|l|}{ TCS/industrial area objects } \\
\hline \multirow[t]{2}{*}{ Heat density $\left(\mathrm{kWh}_{\mathrm{th}} / \mathrm{m}^{2} \mathrm{a}\right)$} & $<25$ & $>25-50$ & $>50-100$ & $>100-200$ & $>200$ & Total & \multicolumn{2}{|c|}{$\begin{array}{l}\text { Potential suitability for DHN } \\
\left(>50 \mathrm{kWh}_{\mathrm{th}} / \mathrm{m}^{2} \mathrm{a}\right)\end{array}$} \\
\hline & & & & & & & Count & $\%$ \\
\hline No. of objects in class & 3291 & 6847 & 19,086 & 33,670 & 43,918 & 106,811 & 96,674 & 90.5 \\
\hline
\end{tabular}
Table 7 lists the residential area objects and TCS/

Table 7 Number of residential area objects and TCS/industrial area objects classified by their heat density 
industrial area objects based on their heat density. Here, the data indicates a clear difference between the two types of heat sinks. TCS/industrial area objects show a generally higher heat density than residential area objects. This is particularly noticeable in the number of objects with a heat density higher than $50 \mathrm{kWh}$ th $/ \mathrm{m}^{2}$ a (the previously defined minimum heat density for a DHN). The vast majority (91\%) of the TCS/industrial area objects have a heat density above this value; $41 \%$ even exhibit values of more than $200 \mathrm{kWh}$ th $/ \mathrm{m}^{2}$ a. For the residential area objects, on the other hand, only approximately $7 \%$ of all objects have a heat density of 50 $\mathrm{kWh}_{\mathrm{th}} / \mathrm{m}^{2} \mathrm{a}$ or higher. Almost $75 \%$ exhibit heat density values of less than $25 \mathrm{kWh}$ th $/ \mathrm{m}^{2} \mathrm{a}$.

A visual representation of this data for the categories residential sector and TCS/industrial sector is presented in Fig. 7. This section of a city depicts how the variations in urban fabric produce different values for heat density, making them either more or less suitable for district heating networks. The inner-city areas show higher heat densities (usually more densely built up, more inhabitants per area) whereas the outer areas exhibit lower values (often residential areas with a less dense development).

\section{Technical heat sales potential Total heat sales potential}

Using the previously presented methods, we were able to identify those BEPs which have suitable heat sinks nearby and to quantify the tHSP per category and on the whole. Of the total 14,236 BEPs analyzed, 52\% (7383) have tHSP. The category TCS/industrial is most dominant with 5875 BEPs located next to suitable heat sinks, which is about $80 \%$ of all plants with tHSP. Two thousand four hundred twenty-nine plants have tHSP in the residential sector and 2,096 plants could serve as heat suppliers for LIHC. The detailed figures are presented in Table 8.

When considering the two different options for DHNs, Option A (DHN commencing directly at the BEP site) is suitable for most BEPs. For the categories TCS/industrial and LIHC, Option A is suitable for $85 \%$, and $91 \%$, of the plants respectively, while Option B is only suitable for $15 \%$ and $9 \%$ respectively. In contrast, for the residential sector, the ratio between Option A and Option B (DHN starting from the BEP, raw biogas pipeline to CHPU located at heat sink) is more evenly distributed. Forty-one percent of the BEPs with tHSP could theoretically apply Option B. This is conclusive as the previous chapter has shown that TCS/industrial areas are better suited for DHNs or better qualified as heat consumers, as heat demand and heat density are generally higher in these areas.
Looking at the heat sales potential per category, a similar picture unfolds. The overall tHSP is 153.61 $\mathrm{TWh}_{\mathrm{th}} / \mathrm{a}$ of which more than two-thirds $(69 \%$ or 105.94 $\left.\mathrm{TWh}_{\text {th }} / \mathrm{a}\right)$ correspond to the category TCS/industrial. The residential sector accounts for $30 \%\left(46.15 \mathrm{TWh}_{\mathrm{th}} /\right.$ a), and $1 \%\left(1.52 \mathrm{TWh}_{\text {th }} / \mathrm{a}\right)$ is attributable to LIHC.

The total tHSP of $153 \mathrm{TWh}_{\mathrm{th}} / \mathrm{a}$ corresponds to $17 \%$ of the final energy demand for heating (only space heating and hot water; reference year 2011, which is the point in time of the IZES heat demand figures).

For the residential and TCS/industrial sector categories, this results in a proportion of final energy consumption in the heating sector of $7 \%$ and $38 \%$ respectively. ${ }^{12}$

However, this potential is not evenly distributed among all BEPs with a DHN option. Taking into account all BEPs for which we could determine sufficient tHSP, and using the heat density of the respective heat sinks as an indicator for the feasibility of a DHN, it is possible to identify statistical hot and cold spots. The hot spots represent plants whose heat sinks have heat densities that have a high statistical significance and are surrounded by plants whose heat sinks have equally high heat densities. For the cold spots, the opposite is true. Consequently, it is possible to identify spatial clusters of plants which could be preferable for a heating network. Figure 8 shows all BEPs with tHSP for each category as well as statistical hot and cold spots.

The identified hot spots point to conditions in the corresponding regions that tend to be advantageous for DHNs. In the residential sector, these include a high population density and corresponding housing typologies (i.e., multi-story buildings) [73]. For the category TCS/industrial, we observed hot and cold spots. The hot spots indicate that the BEPs are close to commercial or industrial areas with a high heat demand, whereas the cold spots imply that the heat demand in the areas under observation is low in comparison to surrounding areas.

\section{Economic heat sales potential}

As described in the methodology section, we analyzed the German BEP inventory data to estimate the economic heat sales potential (eHSP) in a step-by-step process (see Fig. 5). Since we limited the scope of this study to looking at the bigger picture, we did not conduct regionally explicit assessments. Therefore, we aggregated single plant data into a set of $20 \mathrm{BEP}$ clusters and further refined the view by splitting each cluster into $20 \%$ shares (quintiles) based on a heat source-sink-ratio

\footnotetext{
${ }^{12}$ The final energy consumption in the heating sector for space heating and hot water (2011) was $916.1 \mathrm{TWh}_{\mathrm{th}} / \mathrm{a}$ of which $631.6 \mathrm{TWh}_{\mathrm{th}} / \mathrm{a}$ were consumed by the residential sector and $281.4 \mathrm{TWh}_{\mathrm{th}} / \mathrm{a}$ by the TCS and industrial sectors [72].
} 


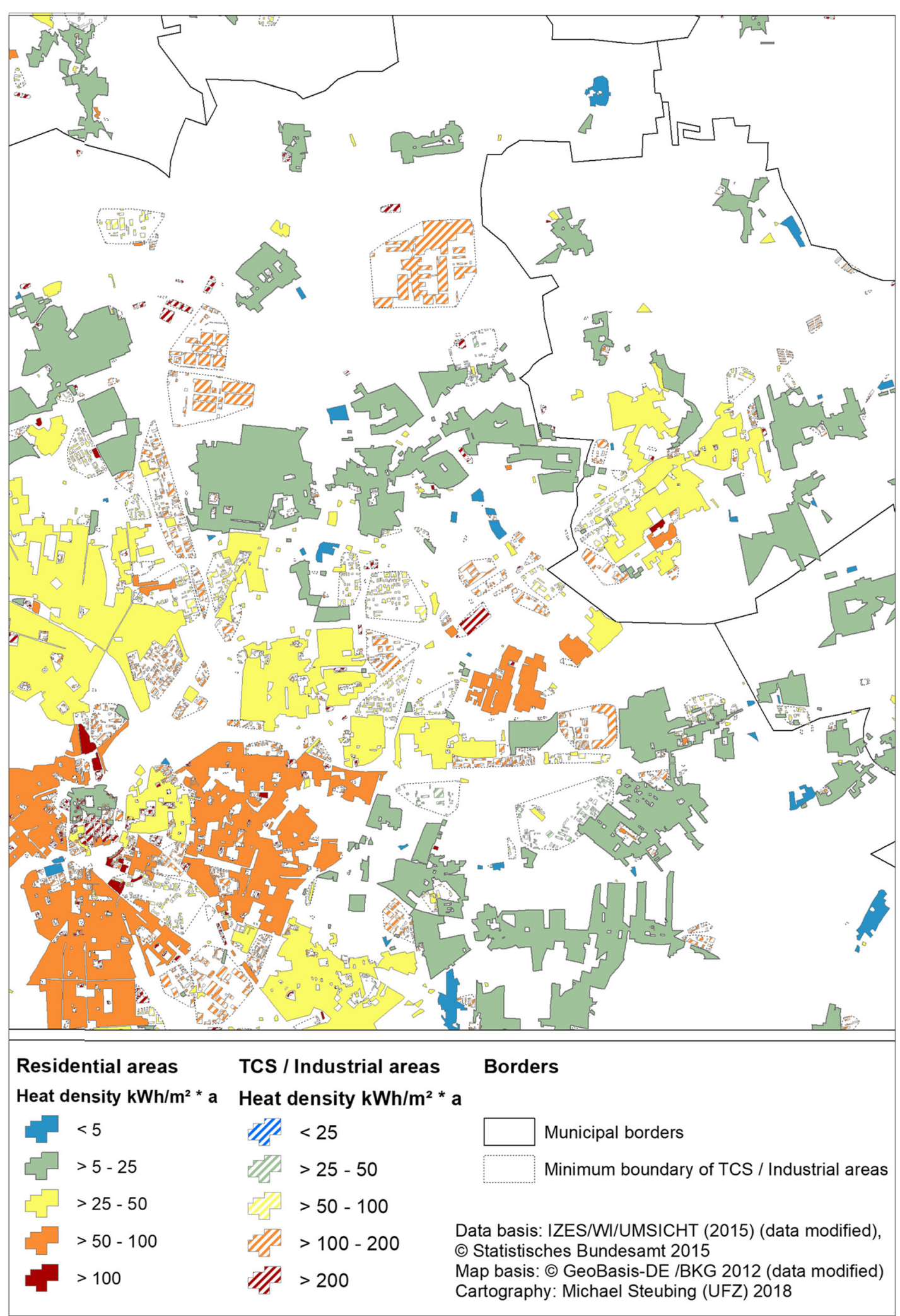

Fig. 7 Example of the heat demand of residential area objects and TCS/industrial area objects modeled at a sub-municipal level 
Table 8 Number of BEP with option for district heating networks and heat sales potential per category

\begin{tabular}{|c|c|c|c|c|}
\hline & Residential & TCS/industrial & Large individual heat consumers ( $\mathrm{LIHC}$ ) & Total \\
\hline \multicolumn{4}{|c|}{ Analyzed BEP } & 14,236 \\
\hline \multicolumn{4}{|c|}{ BEP without district heating network option } & 6853 \\
\hline \multicolumn{4}{|c|}{ BEP with district heating network option } & $7383^{a}$ \\
\hline Option A & 1435 & 4993 & 1916 & -- \\
\hline Option B & 994 & 882 & 180 & -- \\
\hline Total & 2429 & 5875 & 2096 & -- \\
\hline \multicolumn{5}{|c|}{ Heat sales potential $\left[T \mathrm{Wh}_{\mathrm{th}} / \mathrm{a}\right]$} \\
\hline Option A & 34.99 & 94.05 & 1.23 & 130.27 \\
\hline Option B & 11.16 & 11.89 & 0.29 & 23.34 \\
\hline Total & 46.15 & 105.94 & 1.52 & 153.61 \\
\hline
\end{tabular}

${ }^{\mathrm{a}}$ Some of the BEPs have a heat sales potential in more than one category (residential, TCS/industrial, LIHC) and are suitable for Options A and B. The number of plants per category and option can therefore not be added up

(FQ). This ratio represents the available heat generated by an operating BEP divided by the potential heat demand of a heat sink within a maximum distance of 1500 $\mathrm{m}$.

The results for all clusters and their quintiles $\left(Q_{n}\right)$ are presented in Table 9 and show that for some of the quintiles the costs for heat distribution exceed the net earnings and vice versa. The results are quite heterogeneous with deficits reaching 12.8 eurocents per $\mathrm{kWh}$ of electricity produced by BEPs (Cluster $18, \mathrm{Q}_{2}$ ) and potential earnings of up to 16 eurocents per kWh (Cluster 10, $\mathrm{Q}_{5}$ ). Heat sales could be economically viable for $78 \%$ of the assessed BEPs but would generate deficits in $13 \%$ of the cases. Nine percent of the BEP quintiles would not be considered for heat distribution since they only contain BEPs with no potential heat customer in their vicinity $(1500 \mathrm{~m})$. Furthermore, heat sales seem to be economically more viable for the upper quintiles in each cluster (highest FQ).

One of the reasons why the eHSP in the upper quintiles is higher, it is due to the fact that these mostly contain BEP-heat sink-pairs with higher FQ values. Since the quintile distribution was based on the FQ, the proportion of salable heat from BEPs (waste heat) is therefore higher in the upper quintiles and affects the eHSP. Once the FQ exceeds a value of 5, we assumed the maximum cogeneration utilization rate $\left(\mathrm{CUR}_{\max }\right)$ to be $100 \%$ (Fig. 6). In Table 10, we can observe that the 4th and 5th quintiles show values from $92-100 \%$ for $\mathrm{CUR}_{\max }$ in all the clusters. This indicates that at least $40 \%$ of the BEPs within each cluster can possibly supply all, or nearly all, of their net heat production to nearby heat sinks.

Table 9 and Table 10 also display the actual supply potential of the German BEP stock. The overall exhaust heat amount of all 20 clusters totals to a gross value of
37.7 $\mathrm{TWh}_{\mathrm{th}} / \mathrm{a}$ (Table 9). Taking into consideration the different rations for $\mathrm{CUR}_{\max }$, the externally usable heat amounts to $19.1 \mathrm{TWh}_{\mathrm{th}} / \mathrm{a}$ (Table 10) of which 16.3 $\mathrm{TWh}_{\text {th }} / \mathrm{a}$ could be identified economically viable heat sales potential (Table 9).

\section{Discussion}

As the results indicate, the presented methods are a suitable approach for determining the BEP-specific tHSP and subsequently for estimating the eHSP. The required data could be generated by mostly publicy available data sources as described in the method section. The data indicates that there is currently unused potential especially with regard to tHSP but for eHSP too. Most of the BEPs display positive values concerning this matter, especially in the quintiles Q4 and Q5 of the $20 \mathrm{BEP}$-clusters.

The total tHSP of $153 \mathrm{TWh}_{\text {th }} / \mathrm{a}$ corresponds to $17 \%{ }^{13}$ of the final energy demand for space heating [72]. Bioenergy plants in contrast, generate a gross heat amount of $37.7 \mathrm{TWh}_{\mathrm{th}} / \mathrm{a}$, of which $19.1 \mathrm{TWh}_{\mathrm{th}} / \mathrm{a}$ could be used externally (net heat amount). Our results show, that the economically viable supply potential of $16.3 \mathrm{TWh}_{\mathrm{th}} / \mathrm{a}$ (see Table 9) almost covers the net heat generation.

According to most recent energy statistics, biogas plants already generate heat in an order of $15.5 \mathrm{TWh}_{\mathrm{th}} / \mathrm{a}$ [10]. We estimate that the economical heat sales potential for those clusters of plants would be about 11.2 TWh. Thus, assuming that co-generated heat is not solely used for space heating, the order of the calculated potential is closely related to the recent amount. The

\footnotetext{
${ }^{13}$ As previously mentioned, this is the figure for 2011. Latest energy statistics (2018) state an energy demand for space heating and hot water of 764.4 $\mathrm{TWh}_{\mathrm{th}} / \mathrm{a}$ [74]. In this case tHSP corresponds to $20 \%$.
} 


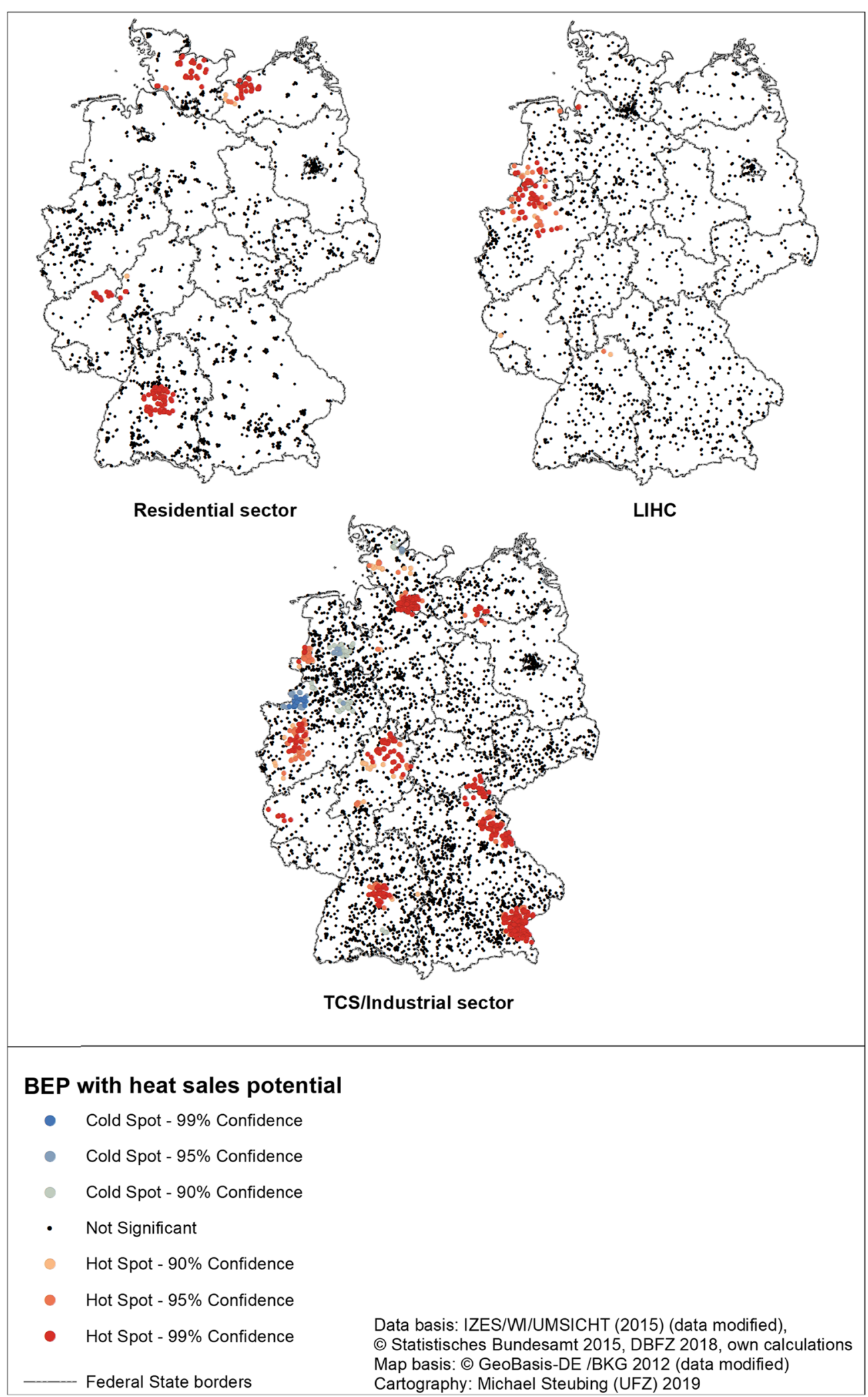

Fig. 8 Statistical hot and cold spots of bioenergy plants with tHSP in relation to the heat density of their nearest heat sink 
Table 9 Annual heat sales potential: net earnings minus annuity of distribution costs

\begin{tabular}{|c|c|c|c|c|c|c|c|c|c|c|c|c|c|}
\hline \multirow{2}{*}{$\begin{array}{c}\text { Cluster } \\
n\end{array}$} & \multicolumn{5}{|c|}{ Specific heat sale balance [Ct/kWhel] } & & \multirow{2}{*}{$\begin{array}{c}\text { Cluster } \\
n\end{array}$} & \multicolumn{5}{|c|}{ Economic heat sale potential (eHSP) [GWh] } & \\
\hline & Q1 & Q2 & Q3 & Q4 & Q5 & & & Q1 & Q2 & Q3 & Q4 & Q5 & \\
\hline 1* & 0.0 & 1.0 & -2.0 & -0.6 & -1.5 & & $1^{*}$ & 0 & 51 & 0 & 0 & 0 & \\
\hline $2^{*}$ & 0.0 & 0.5 & 4.0 & -4.4 & 0.4 & & $2^{*}$ & 0 & 0 & 0 & 0 & 1 & \\
\hline $3^{*}$ & 0.1 & -0.6 & 1.4 & 2.1 & 2.3 & & $3^{*}$ & 69 & 0 & 1,969 & 1,880 & 953 & \\
\hline $4^{*}$ & -0.4 & 0.3 & 1.9 & 2.9 & 3.1 & & $4^{*}$ & 0 & 521 & 1,217 & 1,489 & 786 & \\
\hline $5^{*}$ & -0.3 & 0.3 & 2.3 & 3.0 & 3.0 & & $5^{*}$ & 0 & 198 & 478 & 457 & 271 & \\
\hline $6^{*}$ & -0.4 & 0.6 & 2.8 & 3.2 & 3.3 & & $6^{*}$ & 0 & 110 & 220 & 256 & 117 & \\
\hline $7^{*}$ & 0.2 & 1.0 & 2.4 & 2.0 & 2.8 & & $7^{*}$ & 5 & 24 & 24 & 25 & 12 & \\
\hline $8^{*}$ & 0.0 & 0.2 & 3.2 & 3.2 & 3.2 & & $8^{*}$ & 0 & 3 & 15 & 4 & 3 & \\
\hline $9^{*}$ & 0.8 & 1.9 & 2.1 & 2.1 & 1.9 & & 9* & 18 & 10 & 2 & 1 & 1 & \\
\hline 10 & 0.4 & 7.3 & 11.5 & 11.6 & 11.6 & & 10 & 33 & 201 & 250 & 50 & 45 & \\
\hline 11 & 0.0 & 1.7 & -9.9 & -5.2 & 2.7 & & 11 & 0 & 25 & 0 & 0 & 24 & \\
\hline 12 & 0.0 & -1.1 & 3.6 & 7.4 & 9.1 & & 12 & 0 & 0 & 83 & 110 & 62 & \\
\hline 13 & 0.0 & 3.6 & 13.6 & 15.6 & 16.0 & & 13 & 0 & 187 & 229 & 346 & 104 & \\
\hline 14 & 0.4 & 4.5 & 10.9 & 11.9 & 11.9 & & 14 & 10 & 37 & 82 & 42 & 13 & \\
\hline 15 & 0.0 & 4.6 & 8.6 & 9.1 & 9.2 & & 15 & 0 & 9 & 11 & 14 & 8 & \\
\hline 16 & 0.0 & 3.3 & 3.9 & 4.3 & 4.3 & & 16 & 0 & 2 & 1 & 1 & 2 & \\
\hline 17 & 0.0 & 1.4 & -2.3 & 5.7 & 5.7 & & 17 & 0 & 246 & 0 & 457 & 56 & \\
\hline 18 & 1.2 & -12.8 & 9.0 & 9.0 & 9.0 & & 18 & 96 & 0 & 388 & 77 & 14 & \\
\hline 19 & 0.3 & 2.5 & 4.0 & 3.8 & 4.1 & & 19 & 22 & 414 & 264 & 161 & 59 & \\
\hline \multirow[t]{2}{*}{20} & 0.9 & 4.3 & 4.7 & 4.9 & 4.9 & & 20 & 104 & 297 & 215 & 198 & 45 & \\
\hline & & & & & & $\Sigma$ Q1-Q5 & & & & & & & $\Sigma$ Q1-Q5 \\
\hline$\Sigma_{\text {net }}[T W h]$ & 0.5 & 4.0 & 6.2 & 5.7 & 2.6 & 19.1 & $\sum$ eHSP [TWh] & 0.4 & 2.3 & 5.5 & 5.6 & 2.6 & 16.3 \\
\hline *biogas [TWh] & 0.3 & 1.9 & 4.0 & 4.2 & 2.2 & 12.5 & *biogas [TWh] & 0.1 & 0.9 & 3.9 & 4.1 & 2.1 & 11.2 \\
\hline
\end{tabular}

official energy statistics [74] do not contain disaggregated data for plants fueled by solid biomass, so a similar comparison is not possible here.

These numbers exceed the figures which have been found in energy scenarios for heat supply by local district heating networks in Germany [14]. However, it also displays the high potential of biomass fueled cogeneration plants, which could also provide a noteworthy contribution to renewable heat in Germany.

To unlock this currently unused potential, further investigations on specific constraints are necessary, because the input dataset has some weaknesses. First,

Table 10 Results for the gross exhaust heat amount, the individual CUR $\max$ of the 20 BEP plant clusters

\begin{tabular}{|c|c|c|c|c|c|c|c|c|c|c|c|c|c|}
\hline \multirow{2}{*}{$\begin{array}{c}\text { Cluster } \\
n \\
\end{array}$} & \multicolumn{5}{|c|}{ Exhaust heat amount [GWh] } & & \multirow{2}{*}{$\begin{array}{c}\text { Cluster } \\
n \\
\end{array}$} & \multicolumn{5}{|c|}{ Maximum cogeneration utilization rate $\left(C U R_{\max }\right)[\%]$} & \\
\hline & Q1 & Q2 & Q3 & Q4 & Q5 & & & Q1 & Q2 & Q3 & Q4 & Q5 & \\
\hline $1^{*}$ & 191 & 195 & 95 & 69 & 26 & & $1^{*}$ & $0 \%$ & $26 \%$ & $82 \%$ & $100 \%$ & $100 \%$ & \\
\hline $2^{*}$ & 1 & 3 & 0 & 0 & 1 & & $2^{*}$ & $0 \%$ & $10 \%$ & $100 \%$ & $100 \%$ & $100 \%$ & \\
\hline $3^{*}$ & 2,815 & 3,034 & 2,445 & 1,889 & 953 & & $3^{*}$ & $2 \%$ & $32 \%$ & $81 \%$ & $100 \%$ & $100 \%$ & \\
\hline $4^{*}$ & 2,511 & 1,874 & 1,668 & 1,517 & 786 & & $4^{*}$ & $4 \%$ & $28 \%$ & $73 \%$ & $98 \%$ & $100 \%$ & \\
\hline $5^{*}$ & 1,367 & 715 & 633 & 462 & 271 & & $5^{*}$ & $5 \%$ & $28 \%$ & $76 \%$ & $99 \%$ & $100 \%$ & \\
\hline $6^{*}$ & 256 & 355 & 269 & 256 & 117 & & $6^{*}$ & $4 \%$ & $31 \%$ & $82 \%$ & $100 \%$ & $100 \%$ & \\
\hline $7^{*}$ & 91 & 42 & 26 & 25 & 12 & & $7^{*}$ & $5 \%$ & $58 \%$ & $96 \%$ & $100 \%$ & $100 \%$ & \\
\hline $8^{*}$ & 12 & 12 & 17 & 4 & 3 & & $8^{*}$ & $0 \%$ & $27 \%$ & $91 \%$ & $100 \%$ & $100 \%$ & \\
\hline 9* & 34 & 11 & 2 & 1 & 1 & & 9* & $54 \%$ & $98 \%$ & $100 \%$ & $100 \%$ & $100 \%$ & \\
\hline 10 & 915 & 358 & 253 & 50 & 45 & & 10 & $4 \%$ & $56 \%$ & $99 \%$ & $100 \%$ & $100 \%$ & \\
\hline 11 & 189 & 182 & 227 & 103 & 24 & & 11 & $0 \%$ & $14 \%$ & $64 \%$ & $99 \%$ & $100 \%$ & \\
\hline 12 & 139 & 120 & 152 & 119 & 62 & & 12 & $0 \%$ & $10 \%$ & $55 \%$ & $92 \%$ & $100 \%$ & \\
\hline 13 & 184 & 717 & 291 & 352 & 104 & & 13 & $0 \%$ & $26 \%$ & $78 \%$ & $98 \%$ & $100 \%$ & \\
\hline 14 & 254 & 94 & 102 & 42 & 13 & & 14 & $4 \%$ & $40 \%$ & $81 \%$ & $99 \%$ & $100 \%$ & \\
\hline 15 & 65 & 17 & 12 & 14 & 8 & & 15 & $0 \%$ & $52 \%$ & $95 \%$ & $100 \%$ & $100 \%$ & \\
\hline 16 & 79 & 2 & 2 & 1 & 2 & & 16 & $0 \%$ & $75 \%$ & $89 \%$ & $100 \%$ & $100 \%$ & \\
\hline 17 & 593 & 967 & 628 & 457 & 56 & & 17 & $0 \%$ & $25 \%$ & $89 \%$ & $100 \%$ & $100 \%$ & \\
\hline 18 & 716 & 765 & 388 & 77 & 14 & & 18 & $13 \%$ & $86 \%$ & $100 \%$ & $100 \%$ & $100 \%$ & \\
\hline 19 & 377 & 595 & 265 & 161 & 59 & & 19 & $6 \%$ & $70 \%$ & $100 \%$ & $100 \%$ & $100 \%$ & \\
\hline \multirow[t]{2}{*}{20} & 417 & 327 & 215 & 198 & 45 & & 20 & $25 \%$ & $91 \%$ & $100 \%$ & $100 \%$ & $100 \%$ & \\
\hline & & & & & & ¿Q1-Q5 & & & & & & & $\Sigma \mathrm{Q1}-\mathrm{Q} 5$ \\
\hline$\sum_{\text {gross }}[\mathrm{TWh}]$ & 11.2 & 10.4 & 7.7 & 5.8 & 2.6 & 37.7 & $\sum_{\text {net }}[\mathrm{TWh}]$ & 0.5 & 4.0 & 6.2 & 5.7 & 2.6 & 19.1 \\
\hline *biogas [TWh] & 7.3 & 6.2 & 5.2 & 4.2 & 2.2 & 25.1 & *biogas [TWh] & 0.3 & 1.9 & 4.0 & 4.2 & 2.2 & 12.5 \\
\hline
\end{tabular}

The clusters are divided into 5 quintiles according to the FQ distribution and the resulting accumulated net heat amount 
the heat demand was estimated using primary data representing the status quo in 2011. For modeling the heat demand, influencing factors such as regional climate differences, the refurbishment status of the buildings, or the impact of demographic change were not taken into account. In particular, the latter is likely to have an impact on settlement structures and, as energetic refurbishment progresses; the heat demand in the building sector will decrease. However, the stagnating energy demand for heating and hot water [74] shows that energetic refurbishment of buildings (existing stock and new constructions) is progressing slowly. The impact of this on the model results should be low. Second, data for the TCS/industrial sector does not include the sector-specific demand pattern (temperature level, daily and seasonal demand patterns). In order to assign the exact heat demand to each individual industrial or commercial area, it would also be necessary to know exactly what kind of companies (in terms of industry) are located in a specific area. Detailed feasibility studies, in which the heat demand of the consumers is precisely determined, are always necessary in order to make concrete investment decisions in heating networks. Furthermore, there are a number of hard and soft conditions that a municipality must fulfill in order to ensure that the prerequisites for the economic operation of a DHN are met. These include setting the right regulatory framework, e.g., securing areas in spatial planning or requiring connection to the DHN in certain areas [6].

Third, temperature level constraints, in terms of both the forward and backward flow of potential DHNs, were not considered during the modeling process. This is due to the fact that the DBFZ BEP plant database does not include technical specifications of the respective CHPUs or the temperature levels they are able to provide. Thus, it cannot be assumed that the heat demand of heat consumers requiring higher temperature levels (e.g., process heat for industrial processes) can be completely covered by the heat generated by the corresponding BEP. Nevertheless, the analyzed BEPs should at least be able to contribute to the generation of the required space heating or domestic hot water.

With these uncertainties in mind, the previously stated tHSP for BEP is over- rather than underestimated.

When discussing the results for estimating economic viability, some inadequateness of the methodology should first be clarified. It is important to mention that the described approach for calculating the heat sales potential for all BEP in Germany is based on spatial information, which shows some unavoidable blurring. For example, the location of biomethane CHPs and their corresponding heat sinks may produce results (Q1-Q3) which imply that a significant proportion of that cluster cannot ensure a $\mathrm{CUR}_{\max }$ of $100 \%$. However, it is assumed that all biomethane-CHPs utilize all of their heat, since the remuneration scheme they use within the EEG demands complete cogeneration utilization. It is also important to keep in mind that the results presented here represent mean values calculated for the specific quintiles and therefore only describe the conditions for a group of BEPs. This does not necessarily mean that each individual plant in a cluster can be precisely characterized by the values for the quintiles. Also, the assumption of a direct link between the heat source and the heat sink underestimates real world conditions. Usually, there would be many barriers which lead to additional demands for a heat pipeline. Up to this point, we do not have a suitable approach for identifying empirical data for the extra distance needed. In order to interpret the tHSP results, it needs to be mentioned that we did not include competing heat providers in our analysis. This must be especially be taken into account for the TCS/industrial category where the calculated heat demand is likely to be met by other sources such as excess industrial heat.

The methodology was developed within the project "Bioenergy - potentials, long-term perspectives and strategies for power generation plants after 2020 (BE20plus)" which pursues the aim of evaluating the economic viability of BEPs after they drop out of the EEG's first remuneration period after 20 years. Subsequently, we will use these results to establish which proportion of the recent BEP-portfolio can achieve profitability in a (potentially) second operational period. The findings show that heat sales are not a worthwhile option for some quintiles of the BEP clusters. This is partly due to the fact that there are no suitable heat sinks within the search radius (1500 $\mathrm{m})$ and that the estimated costs for heat distribution exceed the assumed earnings from heat sales. This applies to cases where the heat demand of a heat sink is insufficient and the distance between BEP and heat sink is too far.

In general, even though decreasing electrical efficiency would increase eHSP, power plant operators would not compromise their electricity generation for greater (or exclusive) heat production, since the economic value of heat ${ }^{14}$ is lower than that of electricity within the EEG remuneration scheme.

\section{Conclusion}

In our study, we analyzed the heat sales potential of BEPs within the EEG remuneration scheme in Germany. The results show that, based on our assumptions, $52 \%$ of the BEPs are suitable for distributing heat through a

\footnotetext{
${ }^{14}$ Biogas plant operators received $2.6 \mathrm{ct} / \mathrm{kWh}$ th on average [75].
} 
DHN. The overall technical heat sales potential for these BEPs is approximately $153 \mathrm{TWh}_{\mathrm{th}} / \mathrm{a}$. About two-thirds of this is attributed to the TCS/industrial sector and about one-third to the residential sector. The share of large individual heat consumers in this potential is only about one percent. This total technical heat sales potential is equivalent to almost $12 \%$ of the final energy consumption in the German heating sector. However, this analyzed technical heat sales potential of $153 \mathrm{TWh}_{\mathrm{th}} / \mathrm{a}$ cannot be fully covered by the BEPs identified with the potential for a DHN option. Their gross supply potential for externally usable heat adds up to $19.1 \mathrm{TWh}_{\mathrm{th}} / \mathrm{a}$ and an economically viable supply potential of $16.3 \mathrm{TWh}_{\mathrm{th}} / \mathrm{a}$. The figures on heat sales potential reveal two different aspects. On the one hand, it becomes clear that, in a best-case scenario, only half of the existing BEPs in Germany have the possibility of distributing heat by means of a DHN and generating revenues by doing so. This must be especially taken into account when looking at future possible business segments for BEPs after their EEG remuneration period ends, since those plants are not competitive by generating power only. On the other hand, we identified considerable potentials for DHNs for those BEPs which have heat sinks nearby. These networks can either be fully supplied with biomass or supplemented with other technologies suited for grid-bound heat supply (e.g., larger heat pumps). We conclude that biomass has further potential as a renewable fuel in supplying district heating networks and that the current BEP stock can contribute to increasing the share of RES in the heating sector. Decisive factors in this context are the BEP's relationship to potential heat customers and their specific requirements for heat supply. In order to fully exploit this potential, the BEPs have to be embedded in local or regional heating strategies which take local conditions into account.

With regard to economic viability, it can be concluded that even if there are potential heat consumers within an acceptable distance to the BEP, heat sales are often not an attractive opportunity for all of them since the costs for distributing the heat can exceed the potential earnings. This might change in the medium term with the obligation to include RES into new heating systems, the introduction of $\mathrm{CO}_{2}$-prices and the ban of oil-fired heating systems from 2026 on [76]. These measures are included in a law passed by the German Federal Government at the end of 2019 [77] to achieve its Paris Climate Agreement goals.

The question of heat sales potential is crucial for future business concepts of BEPs, since heat is the most valuable by-product for most of those plants. We are looking forward to integrating the results of this work in a wider approach to cover all factors relevant for BEP profitability.

\section{Appendix}

Table 11 Total network length, distance of BEP to first potential customer and resulting network length factor of 20 existing DHNs fueled by heat generated from biomass in Germany

\begin{tabular}{|c|c|c|c|c|}
\hline Number & Reference & $\begin{array}{l}\text { Total network } \\
\text { length }\left(L_{\text {tot. }}\right) \\
(\mathrm{m})\end{array}$ & $\begin{array}{l}\text { Linear distance of BEP } \\
\text { to first potential } \\
\text { customer }(D)(m)\end{array}$ & $\begin{array}{l}\text { Network } \\
\text { length } \\
\text { factor (NLF }\end{array}$ \\
\hline 1 & [61] & 600 & 14 & 42.86 \\
\hline 2 & [54] & 1200 & 16 & 75.00 \\
\hline 3 & {$[62]$} & 7200 & 30 & 240.00 \\
\hline 4 & {$[64]$} & 2100 & 34 & 61.76 \\
\hline 5 & {$[65]$} & 2300 & 40 & 57.50 \\
\hline 6 & {$[56]$} & 1900 & 434 & 4.37 \\
\hline 7 & {$[60]$} & 1300 & 50 & 26.00 \\
\hline 8 & [58] & 1400 & 65 & 21.54 \\
\hline 9 & {$[66]$} & 450 & 68 & 6.62 \\
\hline 10 & {$[67]$} & 3600 & 68 & 52.94 \\
\hline 11 & [58] & 1160 & 90 & 12.89 \\
\hline 12 & [58] & 505 & 90 & 5.61 \\
\hline 13 & [65] & 7500 & 105 & 71.43 \\
\hline 14 & {$[57]$} & 5000 & 115 & 43.48 \\
\hline 15 & [59] & 2700 & 70 & 38.57 \\
\hline 16 & [55] & 1700 & 210 & 8.10 \\
\hline 17 & {$[65]$} & 6000 & 230 & 26.09 \\
\hline 18 & {$[65]$} & 3500 & 290 & 12.07 \\
\hline 19 & [63] & 9720 & 430 & 22.60 \\
\hline 20 & {$[67]$} & 3500 & 485 & 7.22 \\
\hline \multirow{2}{*}{\multicolumn{3}{|c|}{$\mathrm{NLF}=\frac{L_{\text {tot. }}}{D}$}} & Mean & 41.83 \\
\hline & & & Median & 26.1 \\
\hline
\end{tabular}

Abbreviations

ATKIS: Amtliches Topographisch-Kartographisches Informations System; BEP: Bioenergy plant; CHP: Combined heat and power; CHPU: Combined heat and power unit; $C U R_{\text {max }}$ : Maximum cogeneration utilization rate; DHN: District heating network; DLM: Digital landscape model; eHSP: Economical heat sales potential; FQ: Heat demand-supply factor; HS: Heat storage; OSM: OpenStreetMap; PF: Population factor; Ph@POS: Heat price at the point of sale; PLB: Peak load boiler; Q: Annual heat demand of a heat sink; QF: Q-factor (ratio of heat demand and gross heat supply of a given source); RAF: Residential area factor; RAO: Residential area object: TCS: Trade, commerce and services; tHSP: Technical heat sales potential; TyHS: Type of heat sink

\section{Acknowledgements}

Joint research on this paper has been undertaken by the institutions UFZ, DBFZ, and IZES in the context of the project "Bioenergy - potentials, long-term perspectives and strategies for power generation plants after 2020 (BE20plus)".

\section{Authors' contributions}

Several authors drafted the different parts of the initial version of this manuscript. All authors contributed to the revising and finalizing of the article. All authors read and approved the final manuscript. 


\section{Funding}

This research received funding from the Agency for Renewable Resources e.V. (FNR) and the Federal Ministry for Food and Agriculture (BMEL). The funding bodies had no influence over the design of the study, the interpretation of the data, or the writing of the manuscript.

\section{Availability of data and materials}

The datasets generated and/or analyzed as part of the current study are not publicly available due to the privacy policy of the institutions involved, but are available from the corresponding author upon request.

\section{Ethics approval and consent to participate}

Not applicable

\section{Consent for publication}

Not applicable

\section{Competing interests}

The authors declare that they have no competing interests.

\section{Author details}

${ }^{1}$ Helmholtz Centre for Environmental Research, Permoserstrasse 15, 04318 Leipzig, Germany. ${ }^{2}$ Deutsches Biomasseforschungszentrum gGmbH (DBFZ), Torgauer Strasse 116, 04347 Leipzig, Germany. ${ }^{3}$ Izes gGmbH - Institut für ZukunftsEnergie- und Stoffstromsysteme, Altenkesseler Strasse 17, Geb. A1, 66115 Saarbrücken, Germany.

\section{Received: 16 April 2019 Accepted: 26 February 2020}

\section{Published online: 16 March 2020}

\section{References}

1. UBA [German Environment Agency] (2018) Energieverbrauch für fossile und erneuerbare Wärme. https://www.umweltbundesamt.de/daten/energie/ energieverbrauch-fuer-fossile-erneuerbare-waerme\#textpart-1.

2. European Commission [EC] (2016) Communication from the Commission to the European Parliament, the Council, The European Economic and Social Committee and the Committee of the Regions. An EU Strategy on Heating and Cooling. $\operatorname{COM(2016)} 51$ final on 16.2.2016. EC, Brussels

3. Fleiter T, Elsland R, Rehfeld M, Steinbach J, Reiter U, Catenazzi G, jakob M, Rutten C, Harmsen R, Dittmann F, Rivière P, Stabat P (2017) Heat roadmap Europe. A low-carbon heating and cooling strategy. Profile of heating and cooling demand in 2015. Fraunhofer Institut für System- und Innovationsforschung (ISI), TEP Energy GmbH, University Utrecht, ARMINES, Karlsruhe

4. AGFW [Der Effizienzverband für Wärme Kälte und KWK e.V] (2018) AGFW Hauptbericht 2017. AGFW, Frankfurt am Main

5. Gerhardt N, Sandau F, Becker S, Scholz A, Schumacher P, Schmidt D (2017) Wärmewende 2030. Schlüsseltechnologien zur Erreichung der mittel- und langfristigen Klimaschutzziele im Gebäudesektor. Studie im Auftrag von Agora Energiewende. Fraunhofer-Institut für Windenergie und Energiesystemtechnik (IWES), Fraunhofer-Institut für Bauphysik (IBP), Berlin

6. Baur F, Noll F, Vogler C, Wern B, Mees M, Steinert M, Wiedemeyer N, Beyer S, Hill A, Gebauer M, Pasuchinger T, Kornmann A, Menke C, Barton M (2016) Wärmestudie Region Eifel und Trier. Studie im Auftrag des Ministeriums für Wirtschaft, Klimaschutz, Energie und Landesplanung des Landes RheinlandPfalz. IZES gGmbH, SWT Stadtwerke Trier AöR, Energieagentur Region Trier $\mathrm{GmbH}$, Kompetenzzentrum Solar der Hochschule Trier, ECOSCOP Gesellschaft für Umweltberatung und -recherche mbH Trier, Solites -Steinbeis Forschungsinstitut für solare und zukunftsfähige thermische Energiesysteme (Zuständigkeit Wärmenetze), Saarbrücken

7. BMWi [Federal Ministry for Economic Affairs and Energy] (2019) Kohleausstieg und Strukturwandel. BMWi. https://www.bmwi.de/Redaktion/ DE/Artikel/Wirtschaft/kohleausstieg-und-strukturwandel.html. Accessed 22. 09.2019

8. Fritz S, Pehnt M (2019) Der Kohleausstieg und die Auswirkungen auf die betroffenen Wärmenetze. Kurzstudie im Auftrag des Bundesministeriums für Umwelt. Naturschutz und nukleare Sicherheit. ifeu, Heidelberg

9. BMWi [Federal Ministry for Economic Affairs and Energy] (2018) Erneuerbare Energien in Zahlen. Nationale und internationale Entwicklung im Jahr 2017. BMWi, Berlin
10. Zeitreihen zur Entwicklung der erneuerbaren Energien in Deutschland unter Verwendung von Daten der Arbeitsgruppe Erneuerbare Energien-Statistik (AGEE-Stat). (2019) https://www.erneuerbare-energien.de/EE/Redaktion/DE/ Downloads/zeitreihen-zur-entwicklung-der-erneuerbaren-energien-indeutschland-1990-2018.pdf; jsessionid=906F1084ED959B25AC4C4B27C0C43 A70?_blob=publicationFile\&v $=22$.

11. Hoffstede U, Stelzer M, Hahn H, Beil M, Krautkremer B, Kasten J, Beyrich W, Holzhammer U (2018) Vorbereitung und Begleitung bei der Erstellung eines Erfahrungsberichts gemäß § 97 Erneuerbare-Energien-Gesetz. Teilvorhaben II a: Biomasse. Zwischenbericht. Erstellt im Auftrag des Bundesministeriums für Wirtschaft und Energie. Fraunhofer-Institut für Energiewirtschaft und Energiesystemtechnik (IEE), Kasse

12. Lund R, Østergaard DS, Yang X, Mathiesen BV (2017) Comparison of lowtemperature district heating concepts in a long-term energy system perspective. International Journal of Sustainable Energy Planning and Management 12:5-18. doi:dx.doi.org/10.5278/ijsepm.2017.12.2

13. FNR [Fachagentur Nachwachsende Rohstoffe e.V.] (2019) Biogas: Faustzahlen. FNR. https://biogas.fnr.de/daten-und-fakten/faustzahlen/. Accessed 19.08.2019

14. Koch M, Hennenberg K, Hünecke K, Haller M, Hesse T (2018) Rolle der Bioenergie im Strom- und Wärmemarkt bis 2050 unter Einbeziehung des zukünftigen Gebäudebestandes. Öko-Institut e.V, Freiburg, Darmstadt

15. Weinand JM, McKenna R, Fichtner W (2019) Developing a municipality typology for modelling decentralised energy systems. Util Policy 57:75-96. https://doi.org/10.1016/j.jup.2019.02.003

16. Esch T, Taubenböck H, Geiß C, Schillings C, Nast M, Metz A, Heldens W, Keil M (2011) Potenzialanalyse zum Aufbau von Wärmenetzen unter Auswertung siedlungsstruktureller Merkmale. Deutsches Zentrum für Luftund Raumfahrt e.V. (DLR), Deutsches Fernerkundungsdatenzentrum (DFD), Oberpfaffenhofen

17. IZES gGmbH [Institut für ZukunftsEnergie und Stoffstromsysteme] (2017) Wärmekataster Saarland. Abschlussbericht im Auftrag des MWAEV des Saarlandes. IZES gGmbH, Saarbrücken

18. Scheftelowitz M, Becker R, Thrän D (2018) Improved power provision from biomass: a retrospective on the impacts of German energy policy. Biomass and Bioenergy 111:1-12. doi:https://doi.org/10.1016/j.biombioe.2018.01.010

19. BKG [Federal Agency for Cartography and Geodesy] Digitale Landschaftsmodelle und Landbedeckungsmodelle von Deutschland. Digitales Basis-Landschaftsmodell (Basis-DLM). https://www.bkg.bund.de/DE/ Produkte-und-Services/Shop-und-Downloads/Digitale-Geodaten/ Landschaftsmodelle/landschaftsmodelle.html. Accessed 21 Aug 2019

20. Baur F, Noll F, Wern B, Vogler C, Weiler K, Arnold K, Carpantier R, Pietzner K, Samadi S, Wane S, Hiebel M, Dresen B, Nühlen J (2015) Nachhaltige Integration von Bioenergiesystemen im Kontext einer kommunalen Entscheidungsfindung (Komlnteg). Abschlussbericht. Institut für ZukunftsEnergie und Stoffstromsysteme (IZES gGmbH), Wuppertal Institut für Klima, Umwelt und Energie GmbH, Fraunhofer UMSICHT, Saarbrücken, Wuppertal, Oberhausen

21. Verwaltungsgebiete 1:250 000 mit Einwohnerzahlen (Ebenen), Stand 31.12 (VG250-EW 31.12.) (2018) BKG [Federal Agency for Cartography and Geodesy]. Accessed 10.06.2018

22. Geographical Grid of Germany in Lambert-Projection (2015) BKG [Federal Agency for Cartography and Geodesy]. http://www.geodatenzentrum.de/ geodaten/gdz_rahmen.gdz_div?gdz_spr=deu\&gdz_akt_zeile=5\&gdz_anz zeile $=1 \& g d z$ unt zeile $=31 \& g d z$ user id $=0$.

23. Points of Interest (POI-Bund/POI-BPol) (2018) BKG [Federal Agency for Cartography and Geodesy]. Accessed 21 Aug 2019

24. OpenStreetMap data for Germany - Buildings (2018) Geofrabrik GmbH and OpenStreetMap Contributors. https://download.geofabrik.de/europe/ germany.html.

25. Ergebnisse des Zensus 2011: Bevölkerung im 100 Meter-Gitter (2015) Destatis [Statistisches Bundesamt]. https://www.zensus2011.de/DE/Home/ Aktuelles/DemografischeGrunddaten.html?nn=3065474.

26. Gaderer M, Lautenbach M, Fischer T, Ebertsch G (2007) Wärmenutzung bei kleinen landwirtschaftlichen Biogasanlagen. Bayerisches Landesamt für Umwelt (LfU), Bayerisches Zentrum für Angewandte Energieforschung e. V. (ZAE Bayern), Augsburg

27. Ergebnisse des Zensus 2011: Bevölkerung nach Jahren und Geschlecht für Gemeinden. (2014) Destatis [Statistisches Bundesamt]. https://www.zensus2 011.de/DE/Home/Aktuelles/DemografischeGrunddaten.html. 
28. IWU [Institut für Wohnen und Umwelt] (2003) Deutsche Gebäudetypologie: Systematik und Datensätze. IWU, Darmstadt

29. Zensusdatenbank - Einwohnerzahl je Hektar. Ergebnisse des Zenus am 09. Mai 2011 pro ha (2015) Destatis [Statistisches Bundesamt]. https:// ergebnisse.zensus2011.de/\#StaticContent:00,

30. Destatis [Statistisches Bundesamt] (2008) Klasifikation der Wirtschaftszweige. Mit Erläuterungen. 2008. Destatis, Wiesbaden

31. Destatis [Statistisches Bundesamt] (2008) Bruttoinlandsprodukt/ Bruttowertschöpfung - Jahressumme - regionale Tiefe: Kreise und krfr Städte. Regionaldatenbank Deutschland der Statistischen Ämter des Bundes und der Länder. Destatis, Wiesbaden

32. Destatis [Statistisches Bundesamt] (2011) Sozialversicherungspflichtig Beschäftigte am Arbeitsort nach Geschlecht und Nationalität - Stichtag 30 06. - regionale Tiefe: Gemeinden, Samt-Nerbandsgemeinden. Regionaldatenbank Deutschland der Statistischen Ämter des Bundes und der Länder. Destatis, Wiesbaden

33. Destatis [Statistisches Bundesamt] (2010) Bruttoinlandsprodukt/ Bruttowertschöpfung - Jahressumme - regionale Tiefe: Kreise und krfr. Städte. Regionaldatenbank Deutschland der Statistischen Ämter des Bundes und der Länder. Destatis, Wiesbaden

34. Almut Kirchner, Schlesinger M, Weinmann B, Hofer P, Rits V, Wünsch M, Koepp M, Kemper L, Zweers U, Straßburg S, Matthes F, Busche J, Graichen V, Zimmer W, Hermann H, Penninger G, Mohr L, Ziesing H-J (2009) Modell Deutschland. Klimaschutz bis 2050. Vom Ziel her denken. Endbericht. Im Auftrag des WWF Deutschland. Prognos AG, Öko-Institut e.V., Basel, Berlin

35. Destatis [Statistisches Bundesamt] (2011) Verarbeitendes Gewerbe, Bergbau u. Gewinnung von Steinen und Erden: Betriebe u. Beschäftigte nach Wirtschaftsabteilungen - Stichtag 30.09. - regionale Tiefe: Kreise u. krfr. Städte. Regionaldatenbank Deutschland der Statistischen Ämter des Bundes und der Länder. Destatis, Wiesbaden

36. VDI Nerband Deutscher Ingenieure] (2014) Richtlinie VDI 3807: Verbrauchskennwerte für Gebäude. Blatt 2: - Verbrauchskennwerte für Heizenergie, Strom und Wasser. vol 3807. VDI, Düsseldorf

37. Schlesiger G (2001) Energie- und wassersparende Maßnahmen in Bädern. 2001 edn. BISp [Federal Institute for Sports Science], Bonn

38. Merker H-J, Nißen S (2006) Energiebericht der Stadt Voerde für das Jahr 2006. Kommunalbetrieb Voerde - Gebäudemanagement, Voerde

39. Stadt Dinslaken (2014) Energiebericht. Stadt Dinslaken Dinslaken

40. Kerpern S (2012) Energiebericht 2012. Stadt Kerpern, Kerpen

41. Stadt Rheinfelden (Baden) (2016) Energiebericht 2016. Stadt Rheinfelden (Baden), Rheinfelden (Baden)

42. Stadt Wiesloch (2005) Energiebericht. Kommunale Liegenschaften. Berichtsjahr 2005. Stadt Wiesloch, Wiesloch

43. Stadtverwaltung Paffenhofen a. d. IIm (2014) Energiebericht 2014. Stadtverwaltung Paffenhofen a. d. IIm, Paffenhofen a. d. IIm

44. Oertli Rohleder Wärmetechnik GmbH (2010) In Sachen Technik. Planungsanleitung Gas-Schwimmbadheizer GX 01150 - 800. Oertli Rohleder Wärmetechnik GmbH, Möglingen

45. Innovations- und Transferinstitut Bingen GmbH (2002) Wärmeversorgung für das Freibad und die Sporthalle in Maikammer. Forstliche Versuchs- und Forschungsanstalt Bingen

46. Blesl M, Kempe S, Ohl M, Fahl U, König A, Jenssen T, Eltrop L (2009) Wärmeatlas Baden-Württemberg - Erstellung eines Leitfadens und Umsetzung für Modellregionen. Universität Stuttgart - Institut für Energiewirtschaft und Rationelle Energieanwendung (IER), Stuttgart

47. Energieagentur Weststeiermark (2003) Energiebedarf der Gartenbaubetriebe - Auswertung der Gartenbaubetriebe. Zusammenfassung. Basierend auf der Projektstudie: Grundlagen für den Einsatz von erneuerbaren Energieträgern wie Biomasse und Solarenergie zur Beheizung und Trocknung im Gartenbau (Endbericht 31. Oktober 2003). Energieagentur Weststeiermark, Stainz

48. Arbeitsgemeinschaft QM Holzheizwerke (2004) Q-Leitfaden. Checkliste Standard, MS1 - MS5. 2004. Centrales Agrar-Rohstoff Marketing- und Energie-Netzwerk e.V. (C.A.R.M.E.N. e.V.), Straubing

49. IZES gGmbH [Institut für ZukunftsEnergie und Stoffstromsysteme], ifeu [Institut für Energie- und Umweltforschung GmbH] (2010) Nachhaltige Biogasnutzung im Raum Trier. Abschlussbericht für die Stadtwerke Trier. IZES gGmbH, ifeu, Trier

50. Daniel J, Scholwin F, Vogt R (2008) Materialband D. Biogasnutzung, im Rahmen des BMU Forschungsvorhabens „Optimierung für einen nachhaltigen Ausbau der Biogaserzeugung und -nutzung in Deutschland, FKZ: 0327544. Heidelberg

51. Scheftelowitz M, Rensberg N, Denysenko V, Daniel-Gromke J, Stinner W, Hillebrand K, Naumann K, Peetz D, Henning C, Thrän D, Beil M, Kasten J, Vogel L (2015) Stromerzeugung aus Biomasse (Vorhaben lla Biomasse). Zwischenbericht Mai 2015. DBFZ [Deutsches Biomasseforschungszentrum gemeinnützige $\mathrm{GmbH}$ ], Fraunhofer Institut für Windenergie und Energiesystemtechnik (IWES), INL GmbH, Helmholtz-Zentrum für Umweltforschung - UFZ, Leipzig

52. C.A.R.M.E.N. e.V. [Centrales Agrar-Rohstoff Marketing- und Energie-Netzwerk e.V.] Nahwärmenetze und Bioenergieanlagen. Ein Beitrag zur effizienten Wärmenutzung und zum Klimaschutz. C.A.R.M.E.N. e.V., Straubing

53. KfW [Kreditanstalt für Wiederaufbau] (2018) Merkblatt: Erneuerbare Energien Premium. Finanzierung von Maßnahmen zur Nutzung Erneuerbarer Energien im Wärmemarkt. KfW, Frankfurt am Main

54. Ökoprojekte Gronbach GmbH (2019) Nahwärme: Wärmenetz Uttenhofen. http://www.oekoprojekte-gronbach.de/index.php?id=79.

55. Gemeinde Buttenwiesen (2019) Das Gute liegt so nah: Nahwärme Buttenwiesen. Gemeinde Buttenwiesen. https://www.buttenwiesen.de/de/ leben-wohnen/energie/nahwaermeversorgung/.

56. Fachzentrum für Energie \& Landtechnik (2016) Nahwärmeversorgung Kastl. Gemeinde Kastl. https:/www.kastl.de/cms_showpdf.php?pdfname= Nahwrmenetz_Kastl.

57. Fachverband Biogas e.V. (2019) Bioenergiedorf Reiffenhausen - Gemeinsinn als Schlüssel zum Erfolg. https://www.biogas-kanns.de/downloads/ Interview_Hartmut_Berndt_Biogas_Journal.pdf.

58. Energievision Frankenwald e.V. (2019) Technische Daten zum Nahwärmenetz in Gössersdorf. Energievision Frankenwald e.V. http://www. energie-frankenwald.de/1338887389-technische-daten-nahwaermenetz.html.

59. EnergieAgentur.NRW GmbH (2012) Biogas von Stadtteil zu Stadtteil - neues Nahwärmenetz in Schmallenberg. EnergieAgentur.NRW GmbH. https:// www.energieagentur.nrw/eanrw/ea/biogas-von-stadtteil-zu-stadtteil-neuesnahwaermenetz-in-schmallenberg. Accessed 13.11.2019

60. DVL [Deutscher Verband für Landschaftspflege e.V.] (2019) Biogasanlage Ribbeck, Brandenburg. DVL [Deutscher Verband für Landschaftspflege e.V.]. https://mulle.lpv.de/praxis-forschung/datenbank/projektdetails/id/ biogasanlage-ribbeck-brandenburg.html. Accessed 13 Nov 2019

61. Dorfgemeinschaft Ebbinghof (2019) Nahwärmenetz. Dorfgemeinschaft Ebbinghof. http://www.ebbinghof-live.de/energiedorf/nahwaermenetz.php.

62. Bioenergiedorf Oberrosphe eG (2019) Bioenergiedorf Oberrosphe eG. Bioenergiedorf Oberrosphe eG. http://www.bioenergiedorf-oberrosphe.de/. Accessed 13.11.2019

63. Berghamer $\mathrm{O}$ (2013) Nahwärmeversorgung in Mardorf. http://www. amoeneburg.de/eigene_dateien/aktuell/2013/pdf/12-043_nahwaerme_in_ mardorf_-_bericht_zur_buergerversammlung_am_18_juni_2013.pdf.

64. Krah A (2017) Bebauungsplan mit integriertem Grünordnungsplan: SO Biogasanlage Oberindling. Pocking

65. Kompetenzzentrum HessenRohstoffe (HeRo) e.V. (2009) Bioenergiedörfer in Hessen - mit Erneuerbaren Energien in die Zukunft. Kompetenzzentrum HessenRohstoffe (HeRo) e.V., Witzenhausen

66. Fuchs G (2013) Praxisbeispiel - Satelitten BHKW: Abwärme für Wohnhäuser undfür einen Gasthof. Lengdorf

67. Agentur für Erneuerbare Energien e.V. (2018) Energie vom Land hält Warm. Agentur für Erneuerbare Energien e.V, Berlin

68. Ahlers E, Seidel M, Burg C, Huber R, Hügging T, Kettrup H, Makrlik N, Renken A, Sachse U, Straub F, Sztochaj T, Geiger B, Kleeberger H, Pätzold K (2007) Abwicklung von Standardlastprofilen. BGW [Bundesverband der deutschen Gas- und Wasserwirtschaft], Bonn

69. Aktualisierte und erweitere Testreferenzjahre (TRY) von Deutschland für mittlere und extreme Witterungsverhältnisse (2019) BBSR [Bundesinstitut für Bau,-Stadt,- und Raumforschung im Bundesamt für Bauwesen und Raumordnung]. Accessed 13 Sep 2019

70. Fallahnejad M, Hartner M, Kranzl L (2018) Fritz S (2018) Impact of distribution and transmission investment costs of district heating systems on district heating potential. Energy Procedia 149:141-150. https://doi.org/ 10.1016/j.egypro.2018.08.178

71. Dotzauer M, Lauer M, Schneider J Servant of two masters? Trade-offs for agricultural biogas plants between flexible power generation and heat cogeneration. In: 24th European Biomass Conference and Exhibition, Amsterdam, 2016. doi:10.5071/24thEUBCE2016-5AO.9.1 
72. AGEB [AG Energiebilanzen e.V.] (2013) Anwendungsbilanzen für die Endenergiesektoren in Deutschland in den Jahren 2010 und 2011, Studie beauftragt vom Bundesministerium für Wirtschaft und Technologie Projektnummer: 23/11. AGEB, Berlin

73. Wolff D, Jagnow K (2011) Untersuchung von Nah- und Fernwärmenetzen. Überlegungen zu Einsatzgrenzen und zur Gestaltung einer zukünftigen. Fern- und Nahwärmeversorgung, Wolfenbüttel, Braunschweig

74. Zahlen und Fakten. Energiedaten (2019) BMWi [Federal Ministry for Economic Affairs and Energy]. http://www.bmwi.de/Navigation/DE/Themen/ energiedaten.html.

75. Herbes C, Halbherr V, Braun L (2018) Preise für die Abgabe von Wärme von Biogasanlagen an Dritte. Agrarbetrieb 2018(1):12-15

76. The German Federal Government (2019) Klimaschutzprogramm 2030 der Bundesregierung zur Umsetzung des Klimaschutzplans 2050. The German Federal Government

77. The German Federal Government (2019) CO2-Ausstoß verbindlich senken. The German Federal Government. https://www.bundesregierung.de/bregde/themen/klimaschutz/kimaschutzgesetz-beschlossen-1679886.

\section{Publisher's Note}

Springer Nature remains neutral with regard to jurisdictional claims in published maps and institutional affiliations.

Ready to submit your research? Choose BMC and benefit from:

- fast, convenient online submission

- thorough peer review by experienced researchers in your field

- rapid publication on acceptance

- support for research data, including large and complex data types

- gold Open Access which fosters wider collaboration and increased citations

- maximum visibility for your research: over $100 \mathrm{M}$ website views per year

At BMC, research is always in progress.

Learn more biomedcentral.com/submissions 